\title{
Demogeografski razvoj Istre od 1945. do 2001.
}

\author{
Ivan Zupanc
}

\begin{abstract}
U radu se analizira demografski razvoj Istre nakon Drugog svjetskog rata. Naglasak je na prostornim razlikama naseljenosti. Određen je vremenski i prostorni intenzitet depopulacije te njezinih posljedica. Na kraju rada, pomoću demografskih kriterija, određena su demografski ugrožena naselja.

Ključne riječi: Istra, stanovništvo, depopulacija, prirodno kretanje, migracija, starenje
\end{abstract}

\section{Population Development of Istria in the Period 1945-2001}

This work analyses the demographic development of Istria after the Second World War. The emphasis is on the spatial differences of population. Temporal and spatial intensity of depopulation has been defined, as well as its consequences. Demographically handicapped settlements were determined by means of demographic criteria at the end of the work.

Key words: Istria, population, depopulation, natural change, migration, ageing

\section{UVOD}

Već i samim prolaskom unutrašnjom Istrom mogu se uočiti neobrađene terase - fosiliziran pejzaž - napuštene kuće, čak i cijela sela odnosno ruralne cjeline i polunapušteni gradići. Na obali i u priobalju potpuno je drukčija slika - odmakao je proces litoralizacije. Pitanja se nameću sama po sebi: zašto postoji takva razlika na tako maloj udaljenosti; kako to da je prostor unutrašnje Istre tako demografski (i ne samo demografski) devastiran i zaboravljen? Upravo je taj prostorni aspekt proučavanja stanovništva područje demogeografskog istraživanja.

Predmet ovog rada su demografske promjene na području Istre od 1945. do 2001. Razmatrat će se prostorne razlike u demografskom razvoju i njihov intenzitet; kada počinju, čime su uzrokovane i koje su im posljedice. Svrha je ovog rada pridonijeti općoj spoznaji o demografskim karakteristikama Istre, a poseban je izazov ocijeniti depopulaciju i njezin budući razvoj tj. prepoznati naselja s tendencijom izumiranja. 
Prostor Istre često je različito definiran. Poluotok svakako obuhvaća slovenski i talijanski dio Istre, no kod istraživanja hrvatskog dijela najčešće je to prostor Istarske županije (bivših sedam općina: Buje, Buzet, Labin, Pazin, Poreč, Pula i Rovinj) kojem se katkad dodaje i prostor bivše općine Opatija. Prostorni obuhvat Istre koji se u ovom radu analizira istovjetan je području Istarske županije ${ }^{1}$, a teritorijalizaciju tj. analiziranu prostornu strukturu čini 10 gradova i 29 općina na koje je županija podijeljena (Zakon o područjima županija, gradova i općina u Republici Hrvatskoj, NN 10/1997, 129/2000, 107/2003) (sl. 1). Većina dosadašnjih radova o demografskoj problematici Istre kao podlogu uzima sedam bivših općina (Brazda 1971; Minčir 1989a, 1991; Bašić 1990; Blažević 1991; Aćimović 1993) čime se dobar dio prostora, osobito depopulacijski, prikrivao. Dominantan prostorni okvir u demografskim radovima do početka 1990-ih bile su bivše općine. Tako Minčir piše o općinama Labin, Pazin i Pula (Minčir 1985, 1986, 1989b), Bartolić i Perentin o Pazinštini (Bartolić i Perentin 1989), a Kušen o utjecaju turizma na demografska kretanja na Poreštini (Kušen 1987).

Odabir takvog prostornog obuhvata u analizama može se objasniti prije svega činjenicom da su u knjigama popisa stanovništva podaci bili iskazivani na važećoj administrativnoteritorijalnoj razini, zatim njihovom dobrom prihvaćenošću (tradicionalni nazivi Bujština, Poreština, Pazinština itd.), ali i nedovoljnom spremnošću istraživača na detaljnije analize (npr. na razini naselja). Izuzetak čini nekolicina radova. Radica je demografski vrednovao naselja (Radica 1980), dok je Baldaš obradio demografski razvoj naselja Beram (Baldaš 2003). Bartolić je obradio demografski razvoj tadašnje mjesne zajednice Karojba što čini osamljen primjer takvog prostornog obuhvata (Bartolić 1983).

Koristeći metodu ankete, neki su autori (geografi) istraživali migracije. Prvi takav rad objavio je Blažević o optantima iz Motovunštine i kolonizaciji Međimuraca u taj kraj (Blažević 1967). Baučić je obradio iseljavanje iz Buzeštine od 1961. do 1970. (Baučić 1970), dok je Nejašmić obradio migracije na Pazinštini poslije Drugog svjetskog rata (Nejašmić 1980).

Konstituiranjem novih općina i gradova, od sredine 1990-ih javljaju se radovi koji se (s više ili manje uspjeha) bave demografskom problematikom na toj prostornoj razini. Tako je Bertić dao pregled promjene broja stanovnika Istarske županije (Bertić 1997), Kopal i dr. obradili su općinu Svetvinčenat (Kopal i dr. 1995), Minčir grad Poreč (Minčir 1995), Bartolić općine Cerovlje i Gračišće (Bartolić 1999, 2002), Zupanc općine i gradove sjeverne Istre (Zupanc 2001a, 2001b), Šiklić općinu Lupoglav (Šiklić 2003), te Žmak grad Buzet (Žmak 2003). Grgurević je, na temelju izabranih kriterija, izradio demografsko vrednovanje naselja sa prostorno-planerskog stajališta (Grgurević 2001).

\section{METODOLOŠKE NAPOMENE}

Da bismo mogli uspoređivati višedesetljetni retrospekt demografskih obilježja na razini novih općina i gradova, bilo je potrebno koristiti podatke na razini naselja te ih svesti na razinu važećeg teritorijalnog ustroja. Budući da je rad temeljen na priručniku M. Korenčića "Naselja i stanovništvo SR Hrvatske 1857 - 1971." uskladili smo promjene od 1. 1. 1976. (stanje u priručniku) do 31. 3. 2001. Naime, popis iz 2001. izdvojio je 648 naselja u Istri 


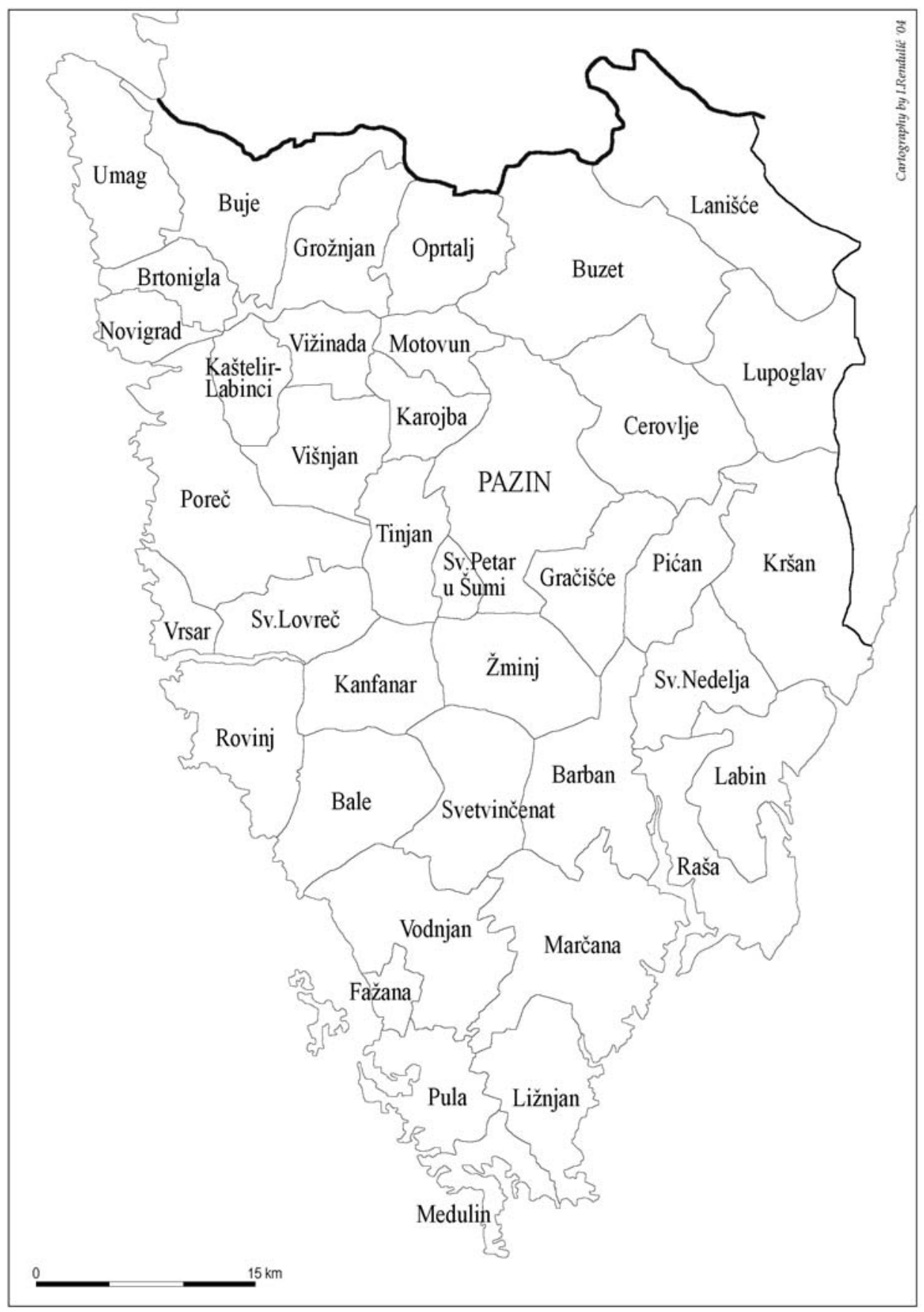

S1. 1. Administrativno-teritorijalna podjela Istarske županije Fig. 1 Administrative-territorial division of County of Istria 
(u vrijeme popisa 1991. bilo ih je 640, a 1981. 636), a Korenčićev priručnik 637. Administrativno-teritorijalnu podjelu Istarske županije čini deset gradova kao jedinica lokalne samouprave koje obuhvaćaju više samostalnih naselja (ekvivalent općini) i 29 općina. Nakon popisa 2001. došlo je do statusne promjene općine Vodnjan u grad Vodnjan (NN 107/2003). Kako je rad temeljen na važećoj općinsko-gradskoj podjeli trebalo je podatke za naselja u popisima od 1948. do 1991. svesti na današnji ustroj. Problem su predstavljali slučajevi u kojima je kod promjena granica naselja ujedno došlo i do promjene granica općine/grada. Nakon popisa 1961. naselje Balići podijeljeno je na dva naselja: Balići I (općina Žminj) i Balići II (općina Barban). Za ukupan broj stanovnika naselja raspolagali smo s podacima od 1948. do 1961. prema Korenčićevom priručniku, ali ne i za strukturna obilježja (dob i spol) te podacima o rođenima i umrlima pa smo u 1961. procijenili broj stanovnika u skupini do 19 godina i u dobi od 60 i više kako bismo mogli izračunati indeks starosti. Isto tako raspodijelili smo broj živorođenih i umrlih od 1964. do 1970.

Drugi slučaj odnosi se na problem razgraničenja grada Pule i općine Medulin. Već i sami podaci o razgraničenju pokazali su se proturiječnim. U Službenim novinama Županije Istarske objavljena je odluka o razdvajanju naselja Banjole (općina Medulin) na pet naselja: Banjole, Vinkuran, Vintijan, Valbonaša i Pješčana Uvala s time da sva naselja ostaju u granicama općine Medulin (SNŽI 4/1996, 183). Prema podatku u popisu stanovništva 2001. naselja Pješčana Uvala, Valbonaša, Vinkuran i Vintijan izdvojena su kao samostalna iz naselja Pula 1996. ${ }^{2}$ Uzevši kao vjerodostojan podatak iz popisa pučanstva, a da bismo mogli uspoređivati podatke u višegodišnjem retrospektu, tretirali smo novonastalu podjelu kao do promjene iz 1996. Dakle, podatku za broj stanovnika grada Pule 2001. pribrojili smo četiri naselja koja su izdvojena, a iz općine Medulin smo isti podatak izdvojili ${ }^{3}$. Isto je učinjeno i s podacima za prirodno kretanje ${ }^{4}$ te za dobnu i spolnu strukturu stanovništva.

Za potrebe razgraničenja nakon Drugog svjetskog rata Jadranski institut iz Sušaka pod vodstvom geografa Josipa Roglića 1. listopada 1945. proveo je popis stanovništva ${ }^{5}$ u Istri kojeg smo također koristili, ali samo za cijelu Istru jer nije usklađena naseljska struktura s ostalim popisima (Roglić 1946). Prvi službeni poslijeratni popis stanovništva proveden je u Istri 15. ožujka 1948. osim za tadašnji kotar Buje (tada dio Zone B STTa) za koji se podaci odnose na 15. prosinca kada je izvršeno prijavljivanje stanovništva za opskrbu. Popis iz 1953. godine također nije proveden u kotaru Buje 31. ožujka kao u ostaloj Istri, nego su podaci uzeti prema registraciji stanovništva koja je provedena 25 . travnja 1956. o čemu je vođeno računa kod izračuna stopa promjene. Idući popisi, 1961., 1971., 1981.,1991. i 2001. provedeni su na cijelom području Istre i svi na isti datum - 31 . ožujka. Dakle, u poslijeratnom razdoblju podaci su mjerodavni za cijelu Istru tek od popisa iz 1961. Posebnu poteškoću predstavlja i promijenjena definicija ukupnog stanovništva u popisu iz 2001. (u ukupan broj stanovnika nekog naselja nisu popisani svi "inozemci" nego se ubraja samo stanovništvo koje u inozemstvu boravi do 12 mjeseci). U slučaju da se izdvoji stanovništvo koje boravi u inozemstvu, korekciju nije moguće izvesti kod strukturnih obilježja stanovništva. Povezano s time, 1991. je popisan iznimno velik broj stanovništva koje radi i boravi u inozemstvu pa smo korigirali podatke za općinu Lanišce gdje je udio stanovništva u inozemstvu 1991. iznosio preko $20 \%$ što je posebno navedeno u tablicama. 
Podaci za rođene i umrle u inozemstvu objavljivani su samo na razini bivših općina do 1992., a od 1993. do 1997. rođeni i umrli u inozemstvu iskazivali su se posebno za svako naselje i to prema prebivalištu majke, odnosno umrle osobe. Dakle, od 1998. primjenjuje se promijenjena definicija prema kojoj se podaci o rođenoj djeci vode za one čija majka ima prebivalište u Republici Hrvatskoj i nije bila odsutna iz zemlje duže od 12 mjeseci, kao i za rođenu djecu majki koje nemaju prebivalište u Republici Hrvatskoj, ali tu borave godinu i duže. ${ }^{6}$

\section{MEĐUPOPISNO KRETANJE BROJA STANOVNIKA 1945. - 2001.}

Razdoblje poslije Drugog svjetskog rata započelo je snažnom depopulacijom. Ukupni broj stanovnika u Istri smanjen je od 1945. do 1948. za 27436 ili 13,0\% (sa 210776 na 183 340), a od 1948. do 1953. za 4,5\% ili prosječno godišnje $0,9 \%$ (tab. $1-3$, sl. 2). Od 1953. pa do 1971. broj stanovnika Istre ustvari stagnira (1953. - 1961. porast od 1\%, a 1961. - 1971. pad od 0,9\%). U većini općina/gradova u tom razdoblju (do 1971.) smanjuje se broj stanovnika (tab.1 -3). Osobitim se intenzitetom depopulacije ističu općine Lanišće na Ćićariji (krška prirodna osnova) i tzv. gornja Bujština (danas uglavnom područje općina Grožnjan i Oprtalj). Obalna središta već su 1960-ih svojim razvojem privlačila brojno stanovništvo iz unutrašnjosti poluotoka, ali i iz bivše države.

Tab. 1. Kretanje broja stanovnika Istre 1948. - 2001. i gustoća naseljenosti 2001.

Tab. 1 Population number change of Istria, 1948-2001 and population density in 2001

\begin{tabular}{|c|c|c|c|c|c|c|c|c|c|}
\hline $\begin{array}{l}\text { Općina/ } \\
\text { grad }\end{array}$ & 1948. & 1953. & 1961. & 1971. & 1981. & 1991. & 2001. & $\begin{array}{c}\text { površina } \\
\left(\mathrm{km}^{2}\right)\end{array}$ & $\mathrm{st} / \mathrm{km}^{2}$ \\
\hline Bale & 1.961 & 1.439 & 1.130 & 1.038 & 1.014 & 1.064 & 1.047 & 82,32 & 12,7 \\
\hline Barban & 4.300 & 4.291 & 4.107 & 3.561 & 3.014 & 2.983 & 2.802 & 90,03 & 31,1 \\
\hline Brtonigla & 2.892 & 1.869 & 1.958 & 1.523 & 1.446 & 1.398 & 1.579 & 31,90 & 49,5 \\
\hline Buje & 7.985 & 5.759 & 5.340 & 4.374 & 4.957 & 5.421 & 5.340 & 99,46 & 53,7 \\
\hline Buzet & 9.521 & 8.838 & 7.088 & 5.895 & 6.168 & 6.295 & 6.059 & 167,22 & 36,2 \\
\hline Cerovlje & 3.834 & 3.607 & 3.049 & 2.485 & 2.011 & 1.815 & 1.745 & 106,07 & 16,5 \\
\hline Fažana & 799 & 765 & 1.271 & 1.538 & 1.879 & 2.716 & 3.050 & 13,70 & 222,7 \\
\hline Gračišće & 2.744 & 2.625 & 2.150 & 1.815 & 1.570 & 1.456 & 1.433 & 60,15 & 23,8 \\
\hline Grožnjan & 3.475 & 2.344 & 1.861 & 1.078 & 914 & 854 & 785 & 68,42 & 11,5 \\
\hline Kanfanar & 2.595 & 2.483 & 2.269 & 1.943 & 1.713 & 1.574 & 1.457 & 59,69 & 24,4 \\
\hline Karojba & 2.140 & 2.131 & 1.801 & 1.573 & 1.558 & 1.470 & 1.489 & 34,61 & 43,0 \\
\hline $\begin{array}{l}\text { Kaštelir- } \\
\text { Labinci }\end{array}$ & 2.045 & 1.805 & 1.572 & 1.218 & 1.168 & 1.296 & 1.334 & 35,36 & 37,7 \\
\hline Kršan & 5.247 & 4.936 & 4.775 & 3.905 & 3.372 & 3.495 & 3.264 & 126,59 & 25,8 \\
\hline Labin & 7.958 & 9.851 & 10.253 & 10.778 & 12.014 & 13.144 & 12.426 & 72,49 & 171,4 \\
\hline Lanišće & 3.235 & 2.698 & 1.715 & 927 & 624 & \begin{tabular}{r|}
$(492)$ \\
621
\end{tabular} & 398 & 144,03 & 2,8 \\
\hline Ližnjan & 2.837 & 2.659 & 2.636 & 2.247 & 2.221 & 2.371 & 2.945 & 67,68 & 43,5 \\
\hline Lupoglav & 2.107 & 2.483 & 1.782 & 1.357 & 1.111 & 979 & 929 & 92,19 & 10,1 \\
\hline
\end{tabular}


Hrvatski geografski glasnik 66/1 (2004.)

\begin{tabular}{|c|c|c|c|c|c|c|c|c|c|}
\hline Marčana & 5.898 & 5.517 & 5.053 & 4.340 & 3.962 & 3.729 & 3.903 & 130,37 & 29,9 \\
\hline Medulin & 1.832 & 1.713 & 1.822 & 1.697 & 2.443 & 3.407 & 4.748 & 34,56 & 173,7 \\
\hline Motovun & 2.613 & 2.049 & 1.850 & 1.385 & 1.261 & 1.098 & 983 & 33,83 & 29,1 \\
\hline Novigrad & 2.313 & 1.743 & 2.094 & 2.398 & 2.619 & 3.270 & 4.002 & 26,69 & 150,0 \\
\hline Oprtalj & 3.803 & 3.186 & 2.220 & 1.500 & 1.255 & 1.109 & 981 & 60,19 & 16,3 \\
\hline Pazin & 8.685 & 8.537 & 8.389 & 8.158 & 8.903 & 9.369 & 9.227 & 139,52 & 66,1 \\
\hline Pićan & 3.508 & 3.363 & 3.012 & 2.611 & 2.346 & 2.133 & 1.997 & 50,06 & 39,9 \\
\hline Poreč & 9.862 & 8.604 & 8.216 & 8.820 & 11.739 & 14.633 & 17.460 & 138,48 & 126,1 \\
\hline Pula & 21.065 & 28.512 & 37.403 & 47.498 & 56.153 & 62.378 & 59.850 & 53,60 & 1093,3 \\
\hline Raša & 6.796 & 6.549 & 6.373 & 4.821 & 4.460 & 4.124 & 3.535 & 77,66 & 45,5 \\
\hline Rovinj & 8.589 & 6.374 & 7.818 & 9.464 & 11.861 & 13.559 & 14.234 & 77,67 & 183,3 \\
\hline Sv. Nedelja & 4.616 & 4.415 & 4.113 & 3.562 & 3.308 & 3.087 & 2.909 & 59,88 & 48,6 \\
\hline Sv. Lovreč & 2.693 & 2.415 & 1.959 & 1.565 & 1.400 & 1.362 & 1.408 & 52,83 & 26,7 \\
\hline $\begin{array}{l}\text { Svv. Petar u } \\
\text { Šumi }\end{array}$ & 1.165 & 1.173 & 1.123 & 1.057 & 999 & 999 & 1.011 & 14,15 & 71,5 \\
\hline Svetvinčenat & 4.067 & 3.861 & 3.556 & 2.773 & 2.345 & 2.204 & 2.218 & 79,43 & 27,9 \\
\hline Tinjan & 3.389 & 3.259 & 2.591 & 2.243 & 1.999 & 1.820 & 1.770 & 54,00 & 32,8 \\
\hline Umag & 7.127 & 6.900 & 7.558 & 8.162 & 9.936 & 12.348 & 12.901 & 82,18 & 157,0 \\
\hline Višnjan & 4.078 & 3.639 & 3.186 & 2.736 & 2.416 & 2.252 & 2.187 & 63,28 & 34,6 \\
\hline Vižinada & 2.768 & 1.961 & 1.760 & 1.350 & 1.268 & 1.150 & 1.137 & 35,27 & 32,2 \\
\hline Vodnjan & 5.609 & 4.334 & 6.297 & 6.259 & 5.261 & 5.538 & 5.651 & 100,83 & 56,0 \\
\hline Vrsar & 2.229 & 1.469 & 1.310 & 1.575 & 1.955 & 2.295 & 2.703 & 22,71 & 119,0 \\
\hline Žminj & 4.960 & 4.938 & 4.378 & 3.970 & 3.689 & 3.530 & 3.447 & 71,42 & 48,3 \\
\hline ISTRA & 183.340 & 175.094 & 176.838 & 175.199 & 188.332 & 204.346 & 206.344 & $2.810,49$ & 73,4 \\
\hline
\end{tabular}

Napomena: Za grad Pulu 2001. ubrojeni podaci i za naselja Pješčana Uvala, Valbonaša, Vinkuran i Vintijan koji su izuzeti iz općine Medulin.

Općina Lanišće bez "inozemaca” 1991. 492 stanovnika.

Izvor: Korenčić M.,1979: Naselja i stanovništvo SR Hrvatske 1857-1971., JAZU, Zagreb; Popis stanovništva, domaćinstava i stanova 1981., Stanovništvo po naseljima, općinama i zajednicama općina, Dokumentacija 553, RZS SRH, Zagreb, 1984; Popis stanovništva, domaćinstava, stanova i poljoprivrednih gospodarstava

31. ožujak 1991., Stanovništvo u zemlji i inozemstvu po naseljima, Dokumentacija 911, DZS, Zagreb, 1996; Zagreb;

Popis stanovništva, kućanstava i stanova 31. ožujka 2001., CD-ROM, DZS, Zagreb, 2002.

Površine županija, gradova i općina u Republici Hrvatskoj, Državna geodetska uprava, Zagreb, 08. travanj 2002.

Tab. 2. Pokazatelj promjene (indeks) broja stanovnika Istre 1948. - 2001.

Tab. 2 Index of population number change of Istria, 1948-2001

\begin{tabular}{|c|c|c|c|c|c|c|c|}
\hline Općina/grad & $\begin{array}{l}1948 .- \\
1953 .\end{array}$ & $\begin{array}{l}1953 .- \\
1961 .\end{array}$ & $\begin{array}{l}\text { 1961.- } \\
1971 .\end{array}$ & $\begin{array}{l}\text { 1971.- } \\
1981 .\end{array}$ & $\begin{array}{l}\text { 1981.- } \\
1991 .\end{array}$ & $\begin{array}{l}\text { 1991.- } \\
2001 .\end{array}$ & $\begin{array}{c}2001 . / \\
1948 .\end{array}$ \\
\hline Bale & 73,4 & 78,5 & 91,9 & 97,7 & 104,9 & 98,4 & 53,4 \\
\hline Barban & 99,8 & 95,7 & 86,7 & 84,6 & 99,0 & 93,9 & 65,2 \\
\hline Brtonigla & 64,6 & 104,8 & 77,8 & 94,9 & 96,7 & 112,9 & 54,6 \\
\hline Buje & 72,1 & 92,7 & 81,9 & 113,3 & 109,4 & 98,5 & 66,9 \\
\hline
\end{tabular}


Ivan Zupanc - Demogeografski razvoj Istre od 1945. do 2001.

\begin{tabular}{|c|c|c|c|c|c|c|c|}
\hline Buzet & 92,8 & 80,2 & 83,2 & 104,6 & 102,1 & 96,3 & 63,6 \\
\hline Cerovlje & 94,1 & 84,5 & 81,5 & 80,9 & 90,3 & 96,1 & 45,5 \\
\hline Fažana & 95,7 & 166,1 & 121,0 & 122,2 & 144,5 & 112,3 & 381,7 \\
\hline Gračišće & 95,7 & 81,9 & 84,4 & 86,5 & 92,7 & 98,4 & 52,2 \\
\hline Grožnjan & 67,5 & 79,4 & 57,9 & 84,8 & 93,4 & 91,9 & 22,6 \\
\hline Kanfanar & 95,7 & 91,4 & 85,6 & 88,2 & 91,9 & 92,6 & 56,1 \\
\hline Karojba & 99,6 & 84,5 & 87,3 & 99,0 & 94,4 & 101,3 & 69,6 \\
\hline Kaštelir-Labinci & 88,3 & 87,1 & 77,5 & 95,9 & 111,0 & 102,9 & 65,2 \\
\hline Kršan & 94,1 & 96,7 & 81,8 & 86,4 & 103,6 & 93,4 & 62,2 \\
\hline Labin & 123,8 & 104,1 & 105,1 & 111,5 & 109,4 & 94,5 & 156,1 \\
\hline Lanišće & 83,4 & 63,6 & 54,1 & 67,3 & 79,6 & 80,9 & 12,3 \\
\hline Ližnjan & 93,7 & 99,1 & 85,2 & 98,8 & 106,8 & 124,2 & 103,8 \\
\hline Lupoglav & 117,8 & 71,8 & 76,2 & 81,9 & 88,1 & 94,9 & 44,1 \\
\hline Marčana & 93,5 & 91,6 & 85,9 & 91,3 & 94,1 & 104,7 & 66,2 \\
\hline Medulin & 93,5 & 106,4 & 93,1 & 144,0 & 139,5 & 139,4 & 259,2 \\
\hline Motovun & 78,4 & 90,3 & 74,9 & 91,0 & 87,1 & 89,5 & 37,6 \\
\hline Novigrad & 75,4 & 120,1 & 114,5 & 109,2 & 124,9 & 122,4 & 173,0 \\
\hline Oprtalj & 83,8 & 69,7 & 67,6 & 83,7 & 88,4 & 88,5 & 25,8 \\
\hline Pazin & 98,3 & 98,3 & 97,2 & 109,1 & 105,2 & 98,5 & 106,2 \\
\hline Pićan & 95,9 & 89,6 & 86,7 & 89,9 & 90,9 & 93,6 & 56,9 \\
\hline Poreč & 87,2 & 95,5 & 107,4 & 133,1 & 124,7 & 119,3 & 177,0 \\
\hline Pula & 135,4 & 131,2 & 127,0 & 118,2 & 111,1 & 95,9 & 284,1 \\
\hline Raša & 96,4 & 97,3 & 75,6 & 92,5 & 92,5 & 85,7 & 52,0 \\
\hline Rovinj & 74,2 & 122,7 & 121,1 & 125,3 & 114,3 & 105,0 & 165,7 \\
\hline Sv. Nedelja & 95,6 & 93,2 & 86,6 & 92,9 & 93,3 & 94,2 & 63,0 \\
\hline Sv. Lovreč & 89,7 & 81,1 & 79,9 & 89,5 & 97,3 & 103,4 & 52,3 \\
\hline Sv. Petar u Šumi & 100,7 & 95,7 & 94,1 & 94,5 & 100,0 & 101,2 & 86,8 \\
\hline Svetvinčenat & 94,9 & 92,1 & 78,0 & 84,6 & 94,0 & 100,6 & 54,5 \\
\hline Tinjan & 96,2 & 79,5 & 86,6 & 89,1 & 91,0 & 97,3 & 52,2 \\
\hline Umag & 96,8 & 109,5 & 108,0 & 121,7 & 124,3 & 104,5 & 181,0 \\
\hline Višnjan & 89,2 & 87,6 & 85,9 & 88,3 & 93,2 & 97,1 & 53,6 \\
\hline Vižinada & 70,8 & 89,8 & 76,7 & 93,9 & 90,7 & 98,9 & 41,1 \\
\hline Vodnjan & 77,3 & 145,3 & 99,4 & 84,1 & 105,3 & 102,0 & 100,7 \\
\hline Vrsar & 65,9 & 89,2 & 120,2 & 124,1 & 117,4 & 117,8 & 121,3 \\
\hline Žminj & 99,6 & 88,7 & 90,7 & 92,9 & 95,7 & 97,6 & 69,5 \\
\hline ISTRA & 95,5 & 101,0 & 99,1 & 107,5 & 108,5 & 101,0 & 112,5 \\
\hline
\end{tabular}

Napomena: Za općinu Lanišće 1981.-1991. i 1991.-2001. izračunato prema stanovništvu "u zemlji” 1981. i 1991. Za Brtoniglu, Buje, Grožnjan, Novigrad i Umag izračunato prema periodima 1948.-1956. i 1956.-1961.

Izvor: Korenčić M.,1979: Naselja i stanovništvo SR Hrvatske 1857-1971., JAZU, Zagreb; Popis stanovništva, domaćinstava i stanova 1981., Stanovništvo po naseljima, općinama i zajednicama općina, Dokumentacija 553, RZS SRH, Zagreb, 1984; Popis stanovništva, domaćinstava, stanova i poljoprivrednih gospodarstava 31. ožujak 1991., Stanovništvo u zemlji i inozemstvu po naseljima, Dokumentacija 911, DZS, Zagreb, 1996; Zagreb;

Popis stanovništva, kućanstava i stanova 31. ožujka 2001., CD-ROM, DZS, Zagreb, 2002. 
Hrvatski geografski glasnik 66/1 (2004.)

Tab. 3. Prosječna godišnja stopa promjene broja stanovnika Istre 1948. - 2001.

Tab. 3 Population change (\% per annum) of Istria, 1948-2001

\begin{tabular}{|c|c|c|c|c|c|c|c|}
\hline Općina/grad & $\begin{array}{l}1948 .- \\
1953 .\end{array}$ & $\begin{array}{r}\text { 1953.- } \\
1961 .\end{array}$ & $\begin{array}{r}\text { 1961.- } \\
1971 .\end{array}$ & $\begin{array}{l}\text { 1971.- } \\
1981 .\end{array}$ & $\begin{array}{r}\text { 1981.- } \\
1991 .\end{array}$ & $\begin{array}{l}\text { 1991.- } \\
2001 .\end{array}$ & $\begin{array}{c}2001 . / \\
1948 .\end{array}$ \\
\hline Bale & $-6,1$ & $-3,0$ & $-0,8$ & $-0,2$ & 0,5 & $-0,2$ & $-1,1$ \\
\hline Barban & 0,0 & $-0,5$ & $-1,4$ & $-1,7$ & $-0,1$ & $-0,6$ & $-0,8$ \\
\hline Brtonigla & $-5,4$ & 0,9 & $-2,5$ & $-0,5$ & $-0,3$ & 1,2 & $-1,1$ \\
\hline Buje & $-4,0$ & $-1,5$ & $-2,0$ & 1,2 & 0,9 & $-0,2$ & $-0,7$ \\
\hline Buzet & $-1,5$ & $-2,7$ & $-1,8$ & 0,5 & 0,2 & $-0,4$ & $-0,8$ \\
\hline Cerovlje & $-1,2$ & $-2,1$ & $-2,0$ & $-2,1$ & $-1,0$ & $-0,4$ & $-1,4$ \\
\hline Fažana & $-0,9$ & 6,2 & 1,9 & 2,0 & 3,6 & 1,2 & 2,2 \\
\hline Gračišće & $-0,9$ & $-2,5$ & $-1,7$ & $-1,4$ & $-0,8$ & $-0,2$ & $-1,2$ \\
\hline Grožnjan & $-4,9$ & $-4,6$ & $-5,3$ & $-1,6$ & $-0,7$ & $-0,8$ & $-2,4$ \\
\hline Kanfanar & $-0,9$ & $-1,1$ & $-1,5$ & $-1,3$ & $-0,8$ & $-0,8$ & $-1,1$ \\
\hline Karojba & $-0,1$ & $-2,1$ & $-1,4$ & $-0,1$ & $-0,6$ & 0,1 & $-0,7$ \\
\hline Kaštelir-Labinci & $-2,5$ & $-1,7$ & $-2,5$ & $-0,4$ & 1,0 & 0,3 & $-0,8$ \\
\hline Kršan & $-1,2$ & $-0,4$ & $-2,0$ & $-1,5$ & 0,4 & $-0,7$ & $-0,9$ \\
\hline Labin & 4,3 & 0,5 & 0,5 & 1,1 & 0,9 & $-0,6$ & 0,8 \\
\hline Lanišće & $-3,6$ & $-5,6$ & $-6,0$ & $-3,9$ & $-2,3$ & $-2,1$ & $-2,9$ \\
\hline Ližnjan & $-1,3$ & $-0,1$ & $-1,6$ & $-0,1$ & 0,7 & 2,2 & 0,1 \\
\hline Lupoglav & 3,3 & $-4,1$ & $-2,7$ & $-2,0$ & $-1,3$ & $-0,5$ & $-1,5$ \\
\hline Marčana & $-1,3$ & $-1,1$ & $-1,5$ & $-0,9$ & $-0,6$ & 0,5 & $-0,8$ \\
\hline Medulin & $-1,3$ & 0,8 & $-0,7$ & 3,6 & 3,3 & 3,3 & 1,7 \\
\hline Motovun & $-4,8$ & $-1,3$ & $-2,9$ & $-0,9$ & $-1,4$ & $-1,1$ & $-1,7$ \\
\hline Novigrad & $-3,5$ & 3,7 & 1,4 & 0,9 & 2,2 & 2,0 & 1,0 \\
\hline Oprtalj & $-3,5$ & $-4,5$ & $-3,9$ & $-1,8$ & $-1,2$ & $-1,2$ & $-2,2$ \\
\hline Pazin & $-0,3$ & $-0,2$ & $-0,3$ & 0,9 & 0,5 & $-0,2$ & 0,1 \\
\hline Pićan & $-0,8$ & $-1,4$ & $-1,4$ & $-1,1$ & $-1,0$ & $-0,7$ & $-1,0$ \\
\hline Poreč & $-2,7$ & $-0,6$ & 0,7 & 2,8 & 2,2 & 1,8 & 1,0 \\
\hline Pula & 6,0 & 3,4 & 2,4 & 1,7 & 1,1 & $-0,4$ & 1,8 \\
\hline Raša & $-0,7$ & $-0,3$ & $-2,8$ & $-0,8$ & $-0,8$ & $-1,5$ & $-1,2$ \\
\hline Rovinj & $-5,9$ & 2,5 & 1,9 & 2,2 & 1,3 & 0,5 & 0,9 \\
\hline Sv. Nedelja & $-0,9$ & $-0,9$ & $-1,4$ & $-0,7$ & $-0,7$ & $-0,6$ & $-0,9$ \\
\hline Sv. Lovreč & $-2,2$ & $-2,6$ & $-2,2$ & $-1,1$ & $-0,3$ & 0,3 & $-1,2$ \\
\hline Sv. Petar u Šumi & 0,1 & $-0,5$ & $-0,6$ & $-0,6$ & 0,0 & 0,1 & $-0,3$ \\
\hline Svetvinčenat & $-1,0$ & $-1,0$ & $-2,5$ & $-1,7$ & $-0,6$ & 0,1 & $-1,1$ \\
\hline Tinjan & $-0,8$ & $-2,9$ & $-1,4$ & $-1,2$ & $-0,9$ & $-0,3$ & $-1,2$ \\
\hline Umag & $-0,4$ & 1,8 & 0,8 & 2,0 & 2,2 & 0,4 & 1,1 \\
\hline Višnjan & $-2,3$ & $-1,7$ & $-1,5$ & $-1,2$ & $-0,7$ & $-0,3$ & $-1,1$ \\
\hline Vižinada & $-6,8$ & $-1,4$ & $-2,6$ & $-0,6$ & $-1,0$ & $-0,1$ & $-1,6$ \\
\hline Vodnjan & $-5,1$ & 4,6 & $-0,1$ & $-1,7$ & 0,5 & 0,2 & 0,0 \\
\hline Vrsar & $-8,2$ & $-1,4$ & 1,8 & 2,2 & 1,6 & 1,6 & 0,4 \\
\hline Žminj & $-0,1$ & $-1,5$ & $-1,0$ & $-0,7$ & $-0,4$ & $-0,2$ & $-0,7$ \\
\hline ISTRA & $-0,9$ & 0,1 & $-0,1$ & 0,7 & 0,8 & 0,1 & 0,2 \\
\hline
\end{tabular}


Napomena: Za Brtoniglu, Buje, Grožnjan, Novigrad i Umag izračunato prema periodima 1948.-1956. i 1956.1961.

Za općinu Lanišće u periodu 1981.-1991. stopa je izračunata prema stanovništvu "u zemlji”.

Za općinu Lanišće 1991.-2001. stopa je izračunata sa stanovništvom “u zemlji” za 1991. godinu.

Izvor: Korenčić M.,1979: Naselja i stanovništvo SR Hrvatske 1857-1971., JAZU, Zagreb; Popis stanovništva, domaćinstava i stanova 1981., Stanovništvo po naseljima, općinama i zajednicama općina, Dokumentacija 553, RZS SRH, Zagreb, 1984; Popis stanovništva, domaćinstava, stanova i poljoprivrednih gospodarstava 31. ožujak 1991., Stanovništvo u zemlji i inozemstvu po naseljima, Dokumentacija 911, DZS, Zagreb, 1996; Zagreb;

Popis stanovništva, kućanstava i stanova 31. ožujka 2001., CD-ROM, DZS, Zagreb, 2002.

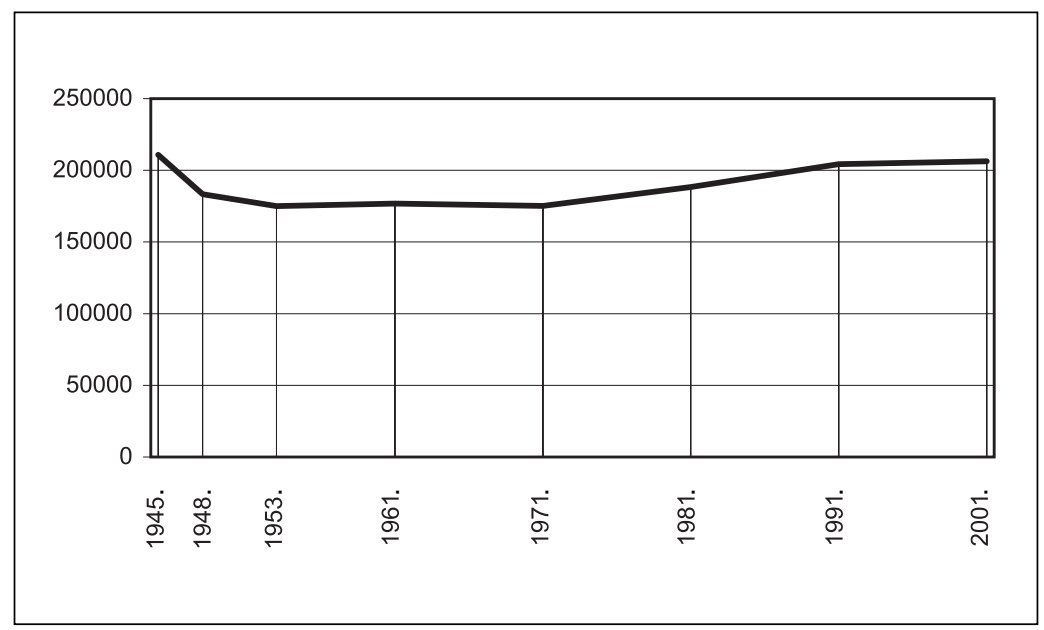

S1. 2. Kretanje broja stanovnika Istre 1945. - 2001.

Fig. 2 The population of Istria, 1945-2001

U iduća dva desetljeća (1971. - 1991.) demografski razvoj Istre najpropulzivniji je u cijelom poslijeratnom razdoblju. Dvanaest općina/gradova u međupopisju 1971. - 1981. ostvarilo je porast broja stanovnika, a 1981. - 1991. čak njih 17. U posljednjem međupopisnom razdoblju (1991. - 2001.) broj općina i gradova u kojima raste broj stanovnika ostao je približno isti (16), ali je ukupan broj stanovnika Istre neznatno porastao (za 1\%), što je dijelom rezultat i spomenute metodološke promjene pri provođenju popisa. Iako su se pozitivni demografski trendovi u posljednjih tridesetak godina počeli širiti iz priobalja u unutrašnjost, podatak da čak 15 općina u svim međupopisnim razdobljima od 1948. do 2001. depopulira, jasno govori o stabilnosti depopulacije. Usporedba 1948. i 2001. otkriva da se broj stanovnika u 12 općina/gradova povećao, a u ostalih 27 smanjio (sl. 3). Najveći porast je u Fažani (indeks 381,7), dok se ekstremnom depopulacijom ističu općine Lanišce $(-87,7 \%)$, Grožnjan $(-77,4 \%)$ i Oprtalj $(-74,2 \%)$.

Gustoća naseljenosti Istre porasla je sa $65,2 \mathrm{st} / \mathrm{km}^{2}$ (1948.) na $73,4 \mathrm{st} / \mathrm{km}^{2}$ (2001.). Izrazitije je diferenciranje prema gustoći naseljenosti na sjeverni, s najrjeđom naseljenošću (Lanišće, Lupoglav, Grožnjan) i krajnji južni dio Istre (Pula, Fažana i Medulin). Polovi gustoće naseljenosti su grad Pula sa $1093 \mathrm{st} / \mathrm{km}^{2}$ i općina Lanišće sa 2,8 st/km² (treća najrjeđe naseljena u Hrvatskoj iza općina Civljane i Udbina). 


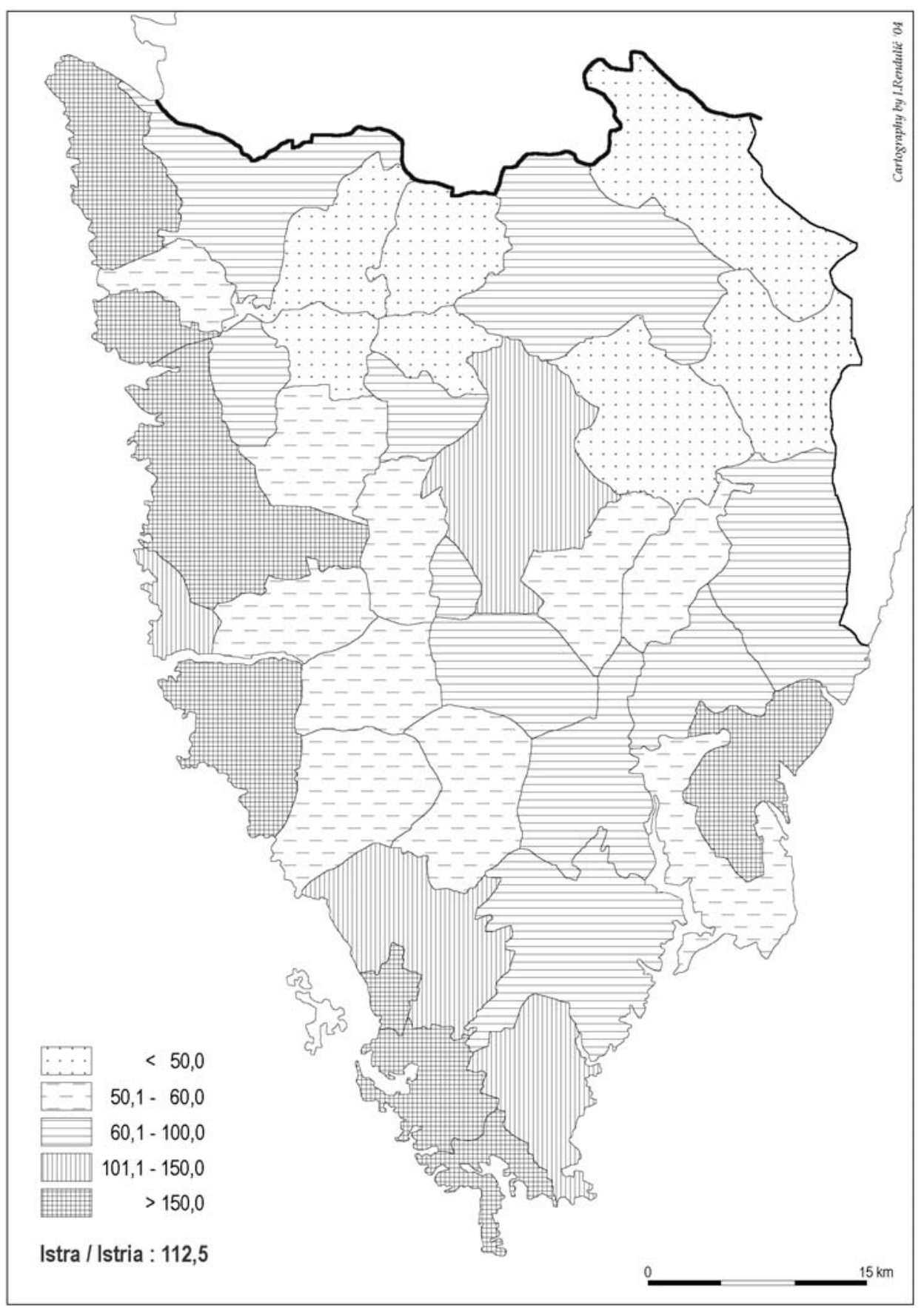

S1. 3. Indeks promjene broja stanovnika Istre po općinama/gradovima 2001./1948.

Fig. 3 Index of population number change of Istria by municipalities/towns (2001/1948) 


\section{DRUŠTVENO-GOSPODARSKE PRILIKE KAO FAKTOR DEMOGRAFSKOG RAZVOJA}

Najprije, obnova poslije Drugog svjetskog rata nije tekla potrebnim koracima ${ }^{7}$ a s obzirom da je Istra nakon rata (osim dijela pod Zonom B) pripala Jugoslaviji, bilo je očekivano da dobije i poseban tretman. On je i ostvaren u obliku Ministarstva za novooslobođene krajeve, ali je ono neshvatljivo brzo ukinuto. Djelovalo je od jeseni 1948. do proljeća 1951. (Zelenika 1973). Nadalje, izrazito agrarnog karaktera, unutrašnja Istra bila je opterećena nepovoljnom poreznom politikom koja za aktivna poljoprivredna gospodarstva nije bila dovoljno ni selektivna ni stimulativna, što je utjecalo na napuštanje poljoprivrede (Zelenika 1973). Isto tako, plaćao se porez na dohodak od poljoprivrede i općinski porez, a individualni proizvođači plaćali su razne druge doprinose kao što su vodni doprinos, imovinska taksa, zdravstveni doprinos i samodoprinos (Zelenika 1973). Deagrarizaciju su dodatno ubrzali usitnjenost posjeda (rascjepkanost parcela), slab prodor mehanizacije u selo i nedostatak kredita. Položaj u kojem se našlo seljaštvo rezultiralo je ubrzanom deagrarizacijom i deruralizacijom (napuštanje sela i poljoprivrede). Prvi popis poslije rata koji nam omogućuje svođenje rezultata po naseljima na razinu novih općina jest onaj iz 1961. Tada je udio poljoprivredog stanovništva iznosio 31,3\%, da bi 2001. pao na svega $2,6 \% .^{8}$

Glavni nedostatak društveno-ekonomskog razvoja Istre jest zanemarivanje prostorne komponente razvoja (Zelenika 1973). Favoriziran je bio obalni dio Istre tj. gradovi u kojima je bila bazirana industrija i razvoj turizma, dok su ulaganja u unutrašnjost poluotoka izostala. Primjerice, bivša općina Buje sredstva koja je dobivala zbog svojeg nerazvijenog dijela, gornje Bujštine (danas uglavnom općine Grožnjan i Oprtalj), ulagala je u razvoj svoje obale, a smatralo se da će onda vlastitim sredstvima obnavljati svoje zaleđe, što nije nikada učinjeno. Niti kriteriji prioriteta u jugoslavenskim mjerilima (nerazvijeni krajevi, strateški razlozi i dr.) nisu išli Istri u prilog (Rojnić i dr. 1973). Jedino veće naselje u unutrašnjosti - Pazin - nije uspjelo razviti znatniji utjecaj na šire područje (Žuljić 1973). Glavni su uzroci tome slaba prometna povezanost, ograničeni gospodarski potencijali unutrašnje Istre i konkurentnost obalnih gradskih središta (Žuljić 1973). Razvoj se bazirao na tadašnjim općinskim centrima kojih je u unutrašnjosti bilo samo tri (Buje, Buzet i Pazin), dok su na obali ostala četiri središta. Ta tri centra nisu mogla ispuniti zadaću nositelja razvoja unutrašnje Istre. Što se tiče prometa, nastojanje da se komunikacija s Rijekom ostvari kao primarni smjer gravitacijske usmjerenosti, nije dala odgovarajuće rezultate $^{9}$ (Žuljić 1973).

Disperzija i usitnjenost bitna su obilježja naseljske strukture Istre. ${ }^{10}$ Takva je struktura nepripremljena dočekala poslijeratni razvoj. Godine 1948., u samo 18 naselja bila je koncentrirana $1 / 3$ stanovništva (to su naselja s više od 1000 stanovnika). ${ }^{11}$ Popis iz 2001. još je više izrazio usitnjenost naselja. Prosječna veličina naselja iznosi 324 stanovnika. U 19 naselja s više od 1000 stanovnika živjelo je čak 129090 ili 62,6\% populacije Istre. ${ }^{12} \mathrm{U}$ ostalih 618 naseobina živjelo je 77254 stanovnika, što znači da je prosječna veličina tih naselja 125 stanovnika. Čak 432 naselja imalo je manje žitelja od tog broja. 


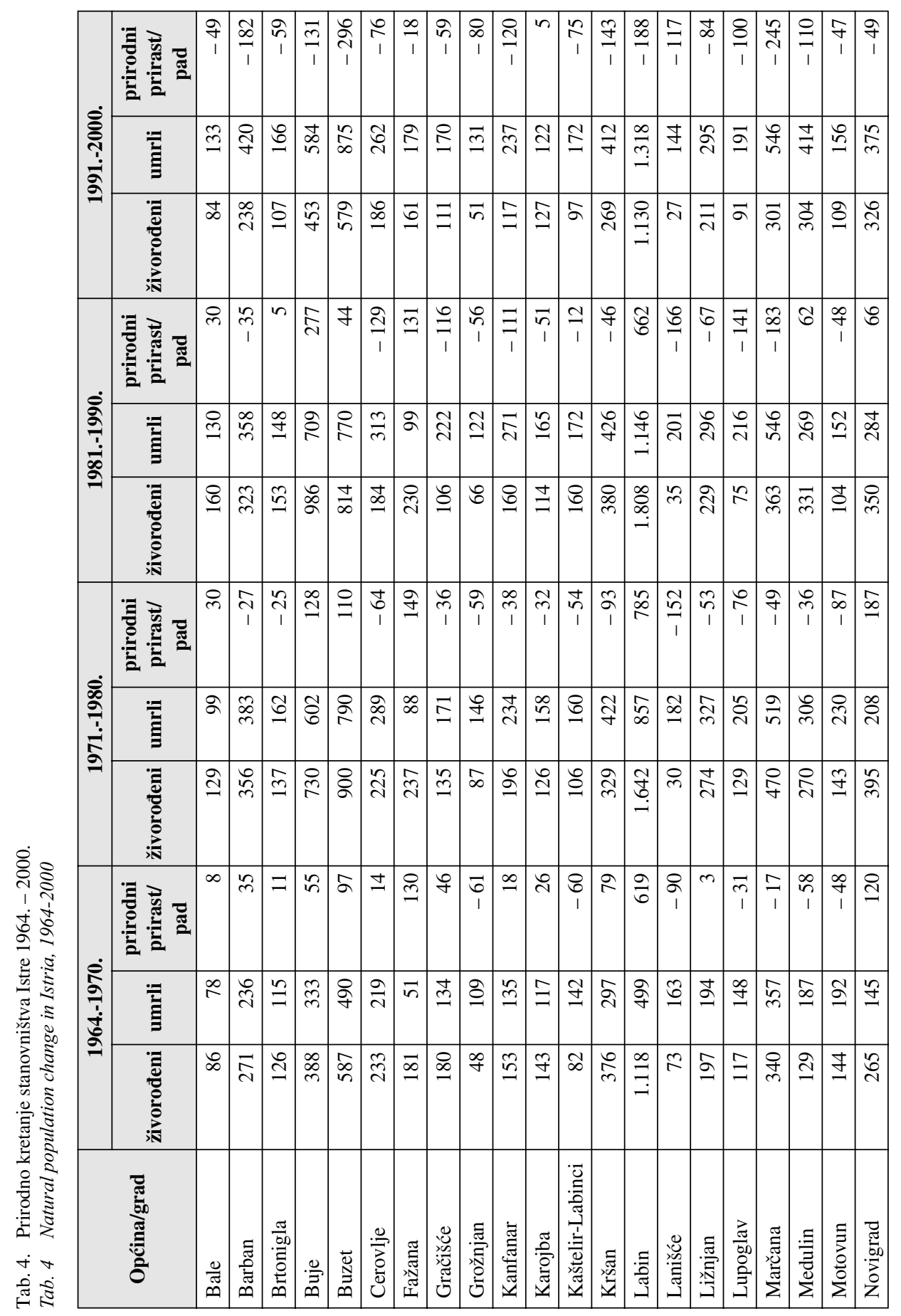




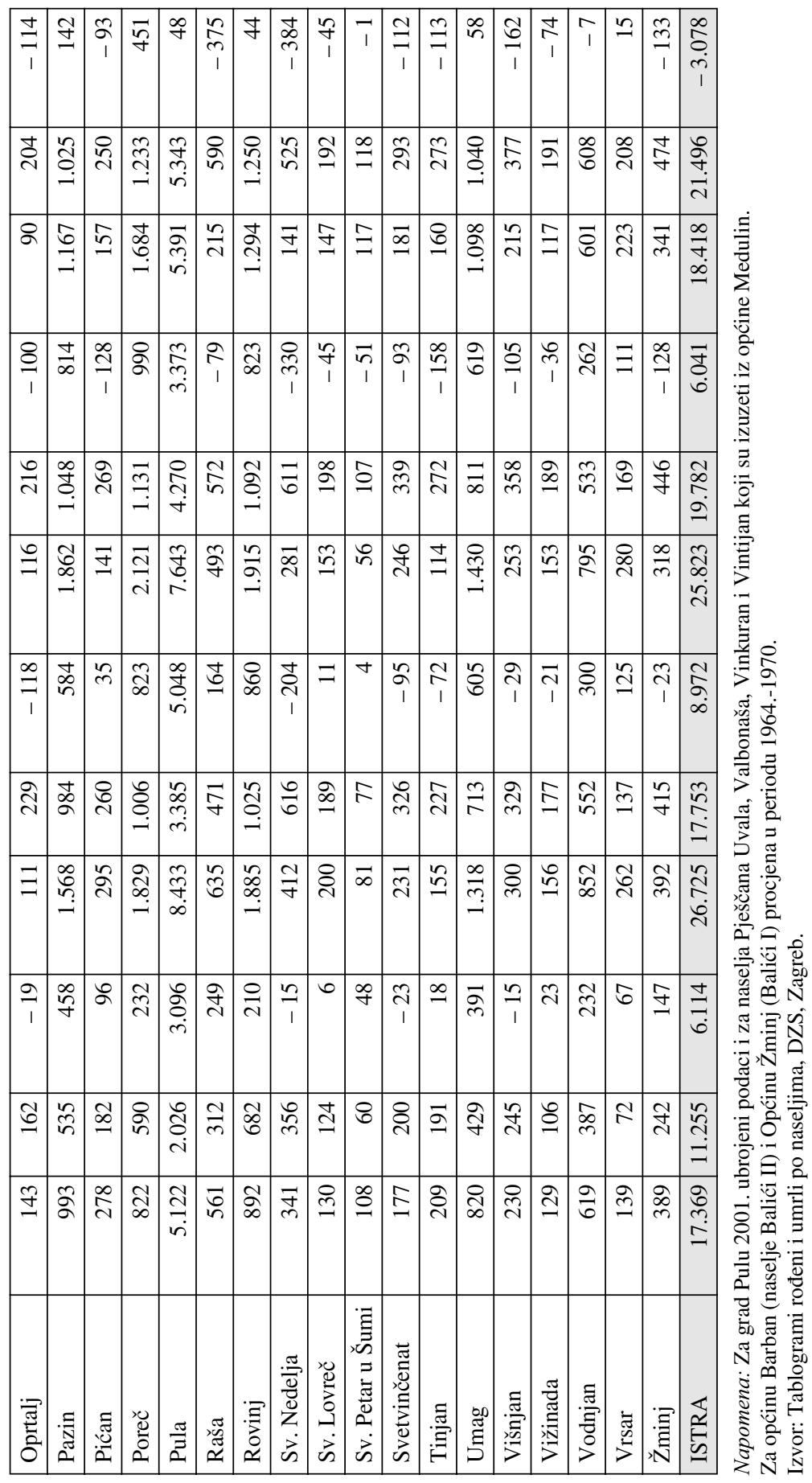




\section{PRIRODNO KRETANJE STANOVNIŠTVA}

Kao jedna od osnovnih odrednica (uz mehaničko kretanje ili migracije) ukupnog kretanja stanovništva, analiza prirodnog kretanja nezaobilazna je u istraživanju demografskog razvoja određenog područja. Analitička podjela na ove dvije komponente nužna je zbog razlikovanja (kvantitativnog i kvalitativnog) udjela/utjecaja na promjenu broja stanovnika i njegove strukturalne promjene.

Daljnje sporije opadanje nataliteta te blaži pad mortaliteta tj. kasnije stagnacija, obilježja su prirodnog kretanja nakon Drugog svjetskog rata. Sredinom 1980-ih (od 1984.) stanovništvo Istarske županije ušlo je u posttranzicijsku etapu demografske tranzicije (sl. 4). Na razini županije denatalitet je prvi put zabilježen 1992. i traje kontinuirano do 2002. (zadnji podatak s kojim raspolažemo).

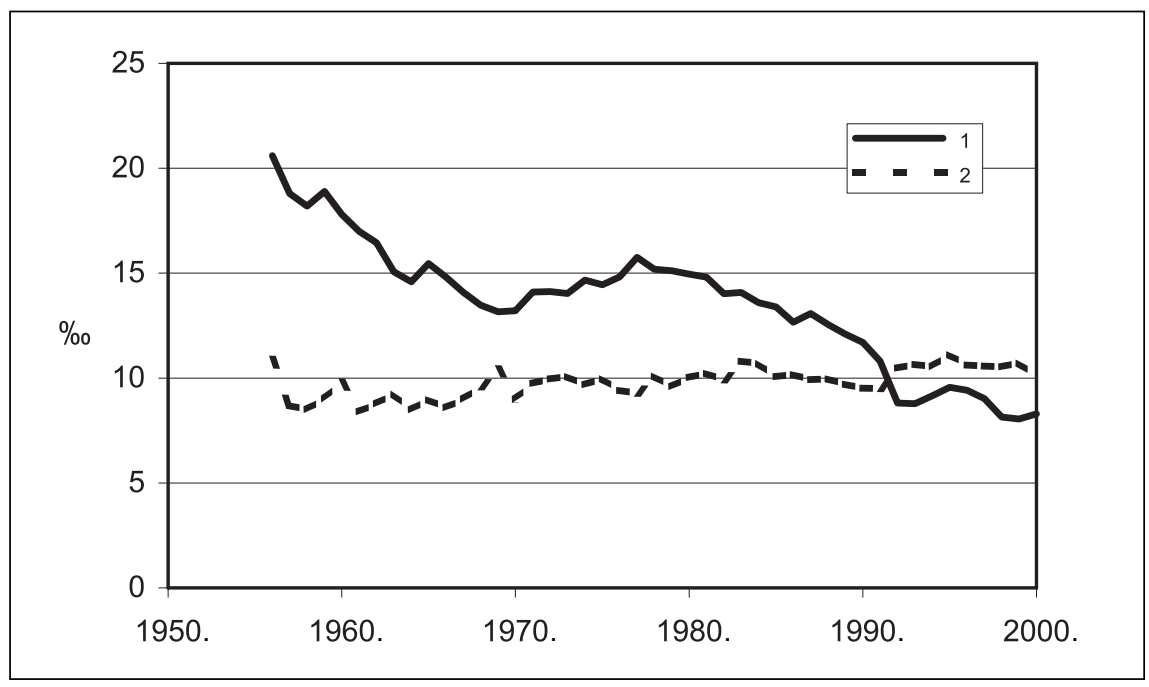

S1. 4. Prirodno kretanje stanovništva Istre 1956. - 2000. (1: rođeni, 2: umrli)

Fig. 4 Natural population change of Istria, 1956-2000 (1: births, 2 deaths)

Na razini naselja, podaci o rođenima i umrlima prate se od 1964. godine pa je svođenje na aktualnu teritorijalnu podjelu općina i gradova u prvoj promatranoj cjelini limitirano na sedmogodišnji period 1964. - 1970. U tom je razdoblju 11 općina imalo više umrlih nego rođenih stanovnika (tab. 4). U idućem desetljeću (1971. - 1980.) taj se broj općina udvostručio (područja gradova bilježe i dalje pozitivan prirodni prirast) na način da se pridružilo novih 11 općina (trend se, dakle, u prijašnjih 11 nastavio), a od 1981. do 1990. broj se povećao na 24 općine. Konačno, u posljednjem međupopisnom razdoblju (1991. -2000.) u 32 ili 82,1\% općina/gradova zabilježen je prirodni pad stanovništva. Demografska tranzicija i odgođeni učinak dugotrajnog iseljavanja iz unutrašnjeg dijela poluotoka jer poznato je da u emigraciji uglavnom sudjeluje stanovništvo u dobi od 20 do 40 godina, (Wertheimer-Baletić 1999) prouzročili su pojavu prirodne depopulacije ponajprije u unutrašnjim općinama Istre, koja se polako širi i u priobalne dijelove. 


\section{MIGRACIJE}

Neto migracijski saldo, za ukupni analizirani period (1945. - 2001.) negativan je i iznosi -4.142 osoba (tab. 5). Vrijednosti negativnog neto migracijskog salda su se apsolutno i relativno smanjivale do 1971. nakon čega poprimaju pozitivan predznak. Za sliku pokretljivosti stanovništva usporedili smo udio “domorodnog” stanovništva 1961. i 2001. godine. Više od polovice populacije Istre 1961. živjelo je u mjestu rođenja (54,4\%). Taj je udio 2001. pao na 46,9\%. Općina s najmanjim udjelom domorodnog stanovništva 1961. bila je Novigrad (24,6\%), dok je ona s najvećim udjelom bila Lanišće (91,0\%).

Tab. 5. Migracijski saldo stanovništva Istre 1945. - 2001.

Tab. 5 Net migration in Istria, 1945-2001

\begin{tabular}{|l|r|r|r|r|r|r|r|}
\hline & $\begin{array}{c}\text { 1945.- } \\
\text { 1948. }\end{array}$ & $\begin{array}{c}\text { 1948.- } \\
\text { 1953. }\end{array}$ & $\begin{array}{c}\text { 1953.- } \\
\text { 1961. }\end{array}$ & $\begin{array}{c}\text { 1961.- } \\
\text { 1971. }\end{array}$ & $\begin{array}{c}\text { 1971.- } \\
\text { 1981. }\end{array}$ & $\begin{array}{c}\text { 1981.- } \\
\text { 1991. }\end{array}$ & $\begin{array}{c}\text { 1991.- } \\
\text { 2001. }\end{array}$ \\
\hline Popisna promjena & -27.436 & -7.956 & 1.744 & -1.639 & 13.133 & 16.014 & 1.998 \\
\hline Prirodni prirast/pad & 3.779 & 9.598 & 14.828 & 10.020 & 8.972 & 6.041 & -3.078 \\
\hline $\begin{array}{l}\text { Neto migracijski } \\
\text { saldo (aps.) }\end{array}$ & -31.215 & -17.554 & -13.084 & -11.659 & 4.161 & 9.973 & 5.076 \\
\hline $\begin{array}{l}\text { Neto migracijski } \\
\text { saldo (rel.) }\end{array}$ & $-4,0$ & $-2,4$ & $-1,9$ & $-1,7$ & 0,6 & 1,3 & 0,6 \\
\hline
\end{tabular}

Relativni neto migracijski saldo $=\mathrm{Ms} /\left(\mathrm{P}_{1}+\mathrm{P}_{2}\right) / 2 \times 100$.

Izvor: Korenčić M., 1979: Naselja i stanovništvo SR Hrvatske 1857-1971, JAZU, Zagreb;

Popis stanovništva, domaćinstava i stanova 1981., Stanovništvo po naseljima, općinama i zajednicama općina, Dokumentacija 553, RZS SRH, Zagreb, 1984;

Popis stanovništva 1991., Stanovništvo u zemlji i inozemstvu po naseljima, Dokumentacija 911, DZS, Zagreb, 1996; Gelo, J. (1987): Demografske promjene u Hrvatskoj od 1780. do 1981., Globus, Zagreb (za prirodni prirast 1945.-1949., str. 275);

Vitalna statistika-izvještaj za godinu 1950, Zavod za statistku i evidenciju NR Hrvatske, Zagreb, 1954; Vitalna statistika-izvještaj za godinu 1951, Zavod za statistku i evidenciju NR Hrvatske, Zagreb, 1955; Vitalna statistika, izvještaj za godinu 1952, Zavod za statistku i evidenciju NR Hrvatske, Zagreb, 1956; Vitalna statistika za 1953, SZS, Beograd, 1956; Vitalna statistika za 1954, SZS, Beograd, 1956;

Vitalna statistika za 1955, SZS, Beograd, 1957; Demografska statistika 1956, SZS, Beograd, 1959;

Demografska statistika 1957, SZS, Beograd, 1960; Demografska statistika 1958, SZS, Beograd, 1960; Demografska statistika 1959, SZS, Beograd, 1962; Demografska statistika 1960, SZS, Beograd, 1963; Demografska statistika 1961, SZS, Beograd, 1964; Demografska statistika 1962, SZS, Beograd, 1964; Demografska statistika 1963, SZS, Beograd, 1965; Tablogrami rođeni i umrli po naseljima, DZS, Zagreb; Popis stanovništva, kućanstava i stanova 31. ožujka 2001., CD-ROM, DZS, Zagreb, 2002.

Prostor poput Istre zahtijevao bi, s obzirom na važnost i opseg migracijskih kretanja, posebnu analitičku obradu, no i sažet prikaz migracijskih tokova kao i analiza migracijskog salda čine se korisnim. Važnost analize migracije očituje se i u činjenici da ona djeluje na strukture stanovništva dvojako. Osim trenutačnog gubitka mlađeg stanovništva koje najčešće sudjeluje u emigraciji, to isto stanovništvo "odnosi" sa sobom i buduće vitalne događaje. Središnju ulogu u demografskom razvoju Istre nakon Drugog svjetskog rata ima iseljavanje koje je uslijedilo kao posljedica ratnih i poratnih zbivanja. Iako egzodus ${ }^{13}$ počinje dva mjeseca prije kapitulacije Italije u rujnu 1943. nakon pada Mussolinija (Dukovski 2001), prve opcije ${ }^{14}$ regulirane su Mirovnim ugovorom s Italijom (stupio na snagu 15. rujna 1947.). Egzodus je time ušao u treću fazu. ${ }^{15}$ Prema člancima 19. i 20. tog ugovora 
i Sporazuma o opciji (Službeni list FNRJ 74/1947, 109/1947) optanti su morali ispunjavati sljedeće uvjete: a) prebivalište na pripojenom području na dan 10. lipnja 1940. (datum ulaska Italije u rat); b) talijansko državljanstvo na dan 15. rujna 1947. (datum stupanja na snagu Mirovnog ugovora); c) talijanski kao govorni jezik. Podnositelji zahtjeva za opcijom morali su priložiti imena i datum rođenja djece ispod 18 godina na koje se proteže opcija.

Drugi sporazum o opcijama potpisan je 1951. (Službeni list FNRJ 1/1951, 12/1951). Rok za podnošenje molbi istjecao je 15. travnja 1951., a tim je sporazumom omogućeno i osobama kojima je zahtijev prije bio odbijen da podnesu molbu za reviziju. Iz dijela pod Zonom B STT-a iseljavanje je legalizirano Memorandumom o suglasnosti (točka 8.) potpisanim 5. listopada 1954. (Službeni list-MUIDS 6/1954). Treći sporazum o opcijama potpisan je 1965. (Službeni list-MUIDS 8/1965). Iako manje korištena, mogućnost iseljenja putem otpusta iz jugoslavenskog državljanstva omogućena je zakonom o jugoslavenskom državljanstvu (Službeni list SFRJ 38/1964) i Osimskim sporazumom koji je stupio na snagu 11. ožujka 1977. (Službeni list-MU 1/1977).

Osim uz pomoć opcija i otpustom iseljavalo se i ilegalno. Takav način iseljavanja bio je najintenzivniji sredinom 1950-ih (1956. i 1957.) zbog slabije granične kontrole nakon tršćanske krize i popuštanja napetosti na granici. Neka istraživanja pokazuju da se od 1956. - 1960. iselilo preko 37\% ukupno ilegalno iseljenih osoba (Laušić 1987).

Na pitanje koliko je osoba iselilo iz Istre (kao i ostalog dijela koji je pripao Jugoslaviji) nikada nećemo dobiti točan odgovor. Poteškoću predstavlja činjenica da je određen broj ljudi iselio ilegalno, a i svi članovi obitelji onih koji su iselili legalno nisu registrirani. Prema podacima u Arhivu MUP-a u Zagrebu, iz Istre je putem opcija iz 1948. i 1951. iselilo 48639 osoba, a otpustom 3964 (do 1974.) (Žerjavić 1993). To ukupno iznosi 52 603 osobe kojima Žerjavić dodaje 20000 iseljenih iz dijela Bujštine (tada pod Zonom B). Ukupni broj iseljenih iznosi 72603 i to predstavlja donju granicu iseljenih iz Istarske županije u sklopu istarskog egzodusa. Ako primjenimo udio iseljenih osoba mlađih od 18 godina $(35,1 \%)$ koji donosi Žerjavić, onda treba dodati još 18438 osoba (35\% od 52603 ). To sada iznosi 91041 emigranata na koje dodajemo 17508 ilegalno iseljenih (19\% od 91 041, prema istom omjeru koji je primijenio Žerjavić). Ukupni broj iseljenih iz hrvatskog dijela Istre popeo se na 108 549, oko 109000 iseljenih nakon Drugog svjetskog rata. ${ }^{16}$

Nakon odlaska optanata neka su se naselja pokušala revitalizirati unutarnjom kolonizacijom. Dalmatinci, pretežno s Makarskog primorja i s otoka Brača, kolonizirali su Vrsar i Funtanu (Blažević 1991), dok su Međimurci doselili u Motovun i okolicu 1951. i 1952. (Blažević 1967). Ugljenokopi na Labinštini privlačili su pak stanovništvo iz cijele bivše Jugoslavije. Pretežno iz sjeverne i sjeverozapadne Bosne, muslimansko stanovništvo nakon Drugog svjetskog rata doselilo je u Labin, Rašu, Vinež, Podpićan i druga naselja (Blažević 1994). Labinština je privukla i Slovence (idrijske rudare) koji su se kasnije vraćali radi bolje mogućnosti zaposlenja u Sloveniji ili su se preselili u priobalna mjesta radi turističkog razvoja (Medica 1995). Istra je općenito bila privlačno područje za naseljavanje u bivšoj Jugoslaviji. Godine 1961. popisano je 6,1\% ili 10782 stanovnika doseljenih s područja tadašnje Jugoslavije (bez Hrvatske) da bi taj broj porastao na 25 108 ili 12,2\% 2001. godine. ${ }^{17}$ 
Ekonomska vanjska emigracija koja se odvijala kao dio ruralnog egzodusa ("bijeg sa sela") isprepliće se i nastavlja na istarski egzodus, a najmasovnija je iz unutrašnjosti poluotoka, što potvrđuje i primjer bivše općine Buzet (Baučić 1970).

U okviru agrarne reforme i kolonizacije koja je u Istri provedena nakon Mirovnog ugovora s Italijom pa do kraja studenog 1948., nije bilo većih preseljenja. Ona su uglavnom bila unutar istarskog poluotoka i to iz tadašnje općine Lanišće (Pavlović 1952). Bez obzira na to što ne postoje precizne kvantifikacije o preseljenju iz unutrašnjosti poluotoka u priobalje (pogotovo za zapadnu i južnu obalu) opća je ocjena da je to dominantan smjer preseljavanja unutar Istre nakon Drugog svjetskog rata. ${ }^{18}$ Migracija iz unutrašnjosti u obalne centre znatno se pojačava od 1960-ih godina razvojem turizma.

\section{TIPOVI OPĆEG KRETANJA STANOVNIŠTVA}

Usporedbom međupopisne promjene broja stanovnika i prirodnoga priraštaja može se odrediti tip općeg (ukupnog) kretanja stanovništva. Tip općeg kretanja stanovništva sintetički je pokazatelj odnosa i utjecaja prirodne promjene (priraštaja ili pada) i prostorne pokretljivosti u određenom razdoblju. Tipovi općeg kretanja mogu biti svrstani u dvije osnovne skupine: emigracijsku ili egzodusnu (E - negativna migracijska bilanca) i imigracijsku (I - pozitivna migracijska bilanca). Svaka se skupina dijeli na četiri tipa, ovisno o modifikaciji prirodnog kretanja i migracijske bilance. Skupina E dijeli se na: $E_{1}$-emigraciju, $E_{2}$-depopulaciju, $E_{3}$-izrazitu depopulaciju i $E_{4}$-izumiranje. Skupina I dijeli se na: $\mathrm{I}_{1}$-ekspanziju imigracijom, $\mathrm{I}_{2}$-regeneraciju imigracijom, $\mathrm{I}_{3}$-slabu regeneraciju imigracijom i $I_{4}$-vrlo slabu regeneraciju imigracijom (Friganović 1990).

U prva dva razmatrana desetljeća (1971. - 1991.) tip općeg kretanja stanovništva Istre imao je obilježje ekspanzije imigracijom (tip $\mathrm{I}_{4}$, tab. 6). Na razini općina, u prvom desetljeću 1971. -1981. najrašireniji tip bio je $\mathrm{E}_{4}$ (trend izumiranja) koji je detektiran u 18 ili 46,2\% općina. Te općine formiraju "prsten" u unutrašnjoj Istri oko gradova Pazina i Buzeta. Egzodusna skupina (24 općina/gradova) bila je brojnija od imigracijske (15 općina i gradova). Kod imigracijskih tipova, najrašireniji je tip $I_{1}$ (ekspanzija imigracijom) koji su imale 11 gradova i općina (redom priobalne ili s jakim općinskim središtima: Buje, Buzet, Pazin itd.). Od 1981. do 1991. omjer imigracijskih i emigracijskih gradova/općina promijenio se u korist prvih, 23:16 (tab. 6). No, i dalje najbrojniji tip $\mathrm{E}_{4}$ koji prevladava uglavnom u istim općinama kao i u prethodnom razdoblju. I kod imigracijskih tipova prevladava ponovno tip $I_{1}$ - ekspanzija imigracijom. Istim općinama iz prethodnog razdoblja (s izuzetkom Pazina) pridružile su se općine Bale, Medulin i grad Vodnjan. Time je cijeli zapadni dio poluotoka poprimio trend ekspanzije imigracijom. U posljednjem međupopisnom periodu (1991. - 2001.) stanovništvo Istre povećavalo se imigracijskim obilježjem, ali isključivo pod utjecajem imigracije (zbog prirodnog pada), tako da je tip općeg kretanja $\mathrm{I}_{3}$ - slaba regeneracija imigracijom (tab. 6). Broj općina i gradova s imigracijskim tipom općeg kretanja stanovništva povećao se na 31 , od čega u njih 15 prevladava tip $\mathrm{I}_{4}$ - vrlo slaba regeneracija imigracijom. Svega pet općina i grad Labin imaju obilježje izumiranja (tip $\mathrm{E}_{4}$ ). Najpogođenija je, dakle, Labinština: općine Kršan, Pićan, Raša i spomenuti grad Labin. 
Hrvatski geografski glasnik 66/1 (2004.)

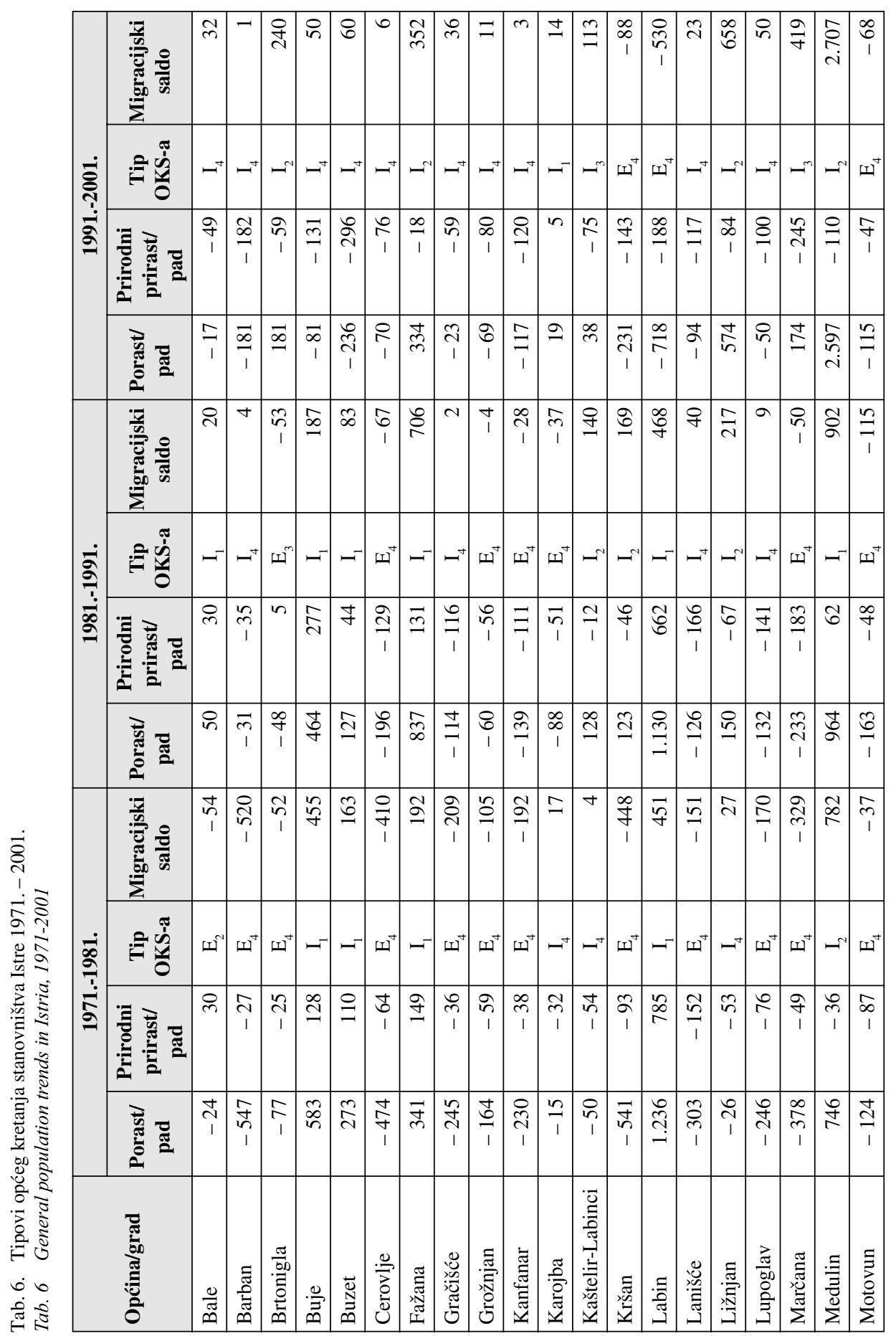




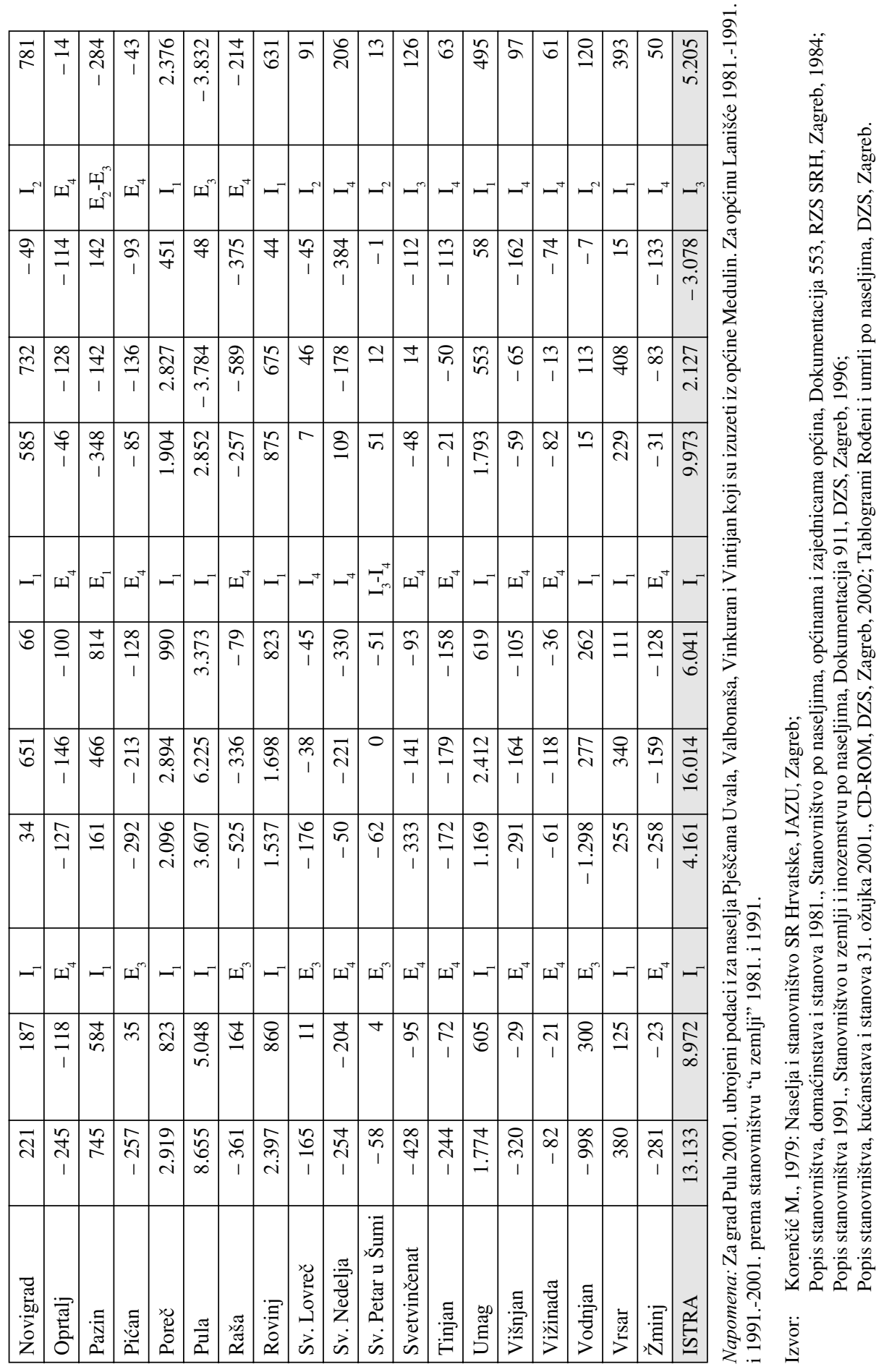


Posebno nas je zanimao odnos prirodnog pada i emigracije u depopulaciji pojedinih općina. Od 27 depopulacijskih općina (1971. - 1981.) kod njih šest depopulacija je uzrokovana isključivo negativnim migracijskim saldom jer je prirodni prirast pozitivan (tipovi $\mathrm{E}_{3} \mathrm{i} \mathrm{E}_{2}$ ). U tri općine ( $\mathrm{tip}_{4}$ ) gubitak stanovništva uzrokovan je isključivo prirodnim padom, a u 18 općina (tip $\mathrm{E}_{4}$ ) zajednički djeluju negativni prirodni prirast i negativni migracijski saldo. Pritom intenzitet gubitka jače određuje emigracija u 11 općina, a u tri prirodni pad (Lanišće, Sv. Nedelja i Motovun). Dakle, od 1971. - 1981. depopulacija stanovništva općina je prvenstveno uzrokovana emigracijom.

U periodu 1981. - 1991. situacija se bitno izmijenila. U samo jednoj općini (Brtonigla) depopulaciju uzrokuje emigracija, a u šest općina samo prirodni pad stanovništva (tip $\mathrm{I}_{4}$ ). Od 14 općina koje depopuliraju zajedničkim djelovanjem negativnog migracijskog salda i prirodnim padom, u njih 11 intenzitet depopulacije je jače generiran prirodnim padom, a u samo tri općine negativnim migracijskim saldom (Motovun, Vižinada, Raša). Depopulacija pod dominantnim utjecajem prirodnog pada nastavila se i potkraj 20. stoljeća (1991. - 2001.). Od 23 depopulirajuće općine/grada, njih 15 gubi stanovništvo isključivo zbog viška umrlih nad rođenima, pet općina depopulira zajedničkim djelovanjem negativnog prirodnog prirasta i emigracije, ali snažnijim utjecajem prirodnog pada. Stanovništvo grada Labina smanjuje se također zajedničkim utjecajem, ali prvenstveno emigracijom, dok samo Pula i Pazin gube stanovništvo isključivim utjecajem mehaničkog kretanja.

\section{SASTAV STANOVNIŠTVA PREMA DOBI I SPOLU}

Sastav stanovništva prema dobi, kao dio bioloških (demografskih) struktura, u analizi neke populacije predstavlja najvažnije strukturalno obilježje. Dobna struktura važna je za sadašnji i budući razvoj stanovništva i gospodarski razvoj nekog područja jer iz nje proizlaze ključni kontingenti stanovništva za biološku reprodukciju (određuje natalitet, mortalitet) i za formiranje radne snage. Dobna struktura slika je povijesnog razvoja stanovništva tijekom duljeg vremenskog razdoblja jer u njoj dolaze do izražaja ranije razvojne tendencije neke populacije (Wertheimer-Baletić 1999). Dobni sastav stanovništva razmatrali smo od 1961. godine pomoću indeksa starosti koji pokazuje odnos starog (60 i više) i mladog (0-19) stanovništva. ${ }^{19}$ Smatra se da je starenje stanovništva već počelo kada indeks prijeđe vrijednost 40,0\%, a udio starog stanovništva dostigne $12 \%$ (WertheimerBaletić 1999). Godine 1961. indeks starosti stanovništva Istre iznosio je 35,4 (tab. 7), a udio starog stanovništva na kritičnoj vrijednosti od $12 \%$ (sl. 6). Udio mladih apsolutno se i relativno smanjuje (1961. 34\%, 2001. 21,8\%), uz, naravno, istovremeno povećanje udjela starih koji su 2001. sa 21,7\% gotovo dostigli udio mladih (sl. 5-7). Već je 1961. 22 ili 56,4\% administrativno-teritorijalnih jedinica prešlo kritičnu vrijednost, a raspon se kretao od 14,9 (općina Fažana) do 93,1 (općina Medulin). Popis iz 2001. otkrio je da su sve općine/gradovi prešli kritičnu vrijednost od 40\%, a čak njih 23 ima više starih nego mladih (indeks preko 100). Indeks starosti stanovništva Istre iznosi 99,7, a prosječna starost (dob) od 40,2 godine potvrđuje odmakao proces starenja (kritična vrijednost je 30 godina; Wertheimer-Baletić 1999). Najmanji indeks starosti imale su općine/gradovi Vrsar (67,3), Poreč $(70,8)$ i Sv. Petar u Šumi $(71,8)$, a najveći Lanišće $(233,8)$, Sv. Nedelja $(151,7)$, Kanfanar $(145,4)$, Barban (145,3) i Marčana $(142,4)$. U tom višedesetljetnom razdoblju 
Tab. 7. Pokazatelj dobne strukture (indeks starosti) stanovništva Istre 1961. i 2001.

Tab. 7 Ageing index of population of Istria in 1961 and 2001

\begin{tabular}{|c|c|c|c|c|c|c|c|}
\hline \multirow{2}{*}{ Općina/grad } & \multicolumn{3}{|c|}{1961.} & \multicolumn{3}{|c|}{2001.} & \multirow{2}{*}{$\begin{array}{c}\text { indeks } \\
2001 . / \\
1961 .\end{array}$} \\
\hline & 0-19 & $60+$ & Xs & 0-19 & $60+$ & Xs & \\
\hline Bale & 430 & 128 & 29,8 & 249 & 212 & 85,1 & 286,0 \\
\hline Barban & 1.492 & 469 & 31,4 & 563 & 818 & 145,3 & 462,2 \\
\hline Brtonigla & 656 & 275 & 41,9 & 379 & 332 & 87,6 & 209,0 \\
\hline Buje & 1.742 & 744 & 42,7 & 1.158 & 1.047 & 90,4 & 211,7 \\
\hline Buzet & 2.337 & 1.101 & 47,1 & 1.328 & 1.190 & 89,6 & 190,2 \\
\hline Cerovlje & 1.039 & 503 & 48,4 & 403 & 498 & 123,6 & 255,3 \\
\hline Fažana & 469 & 70 & 14,9 & 639 & 612 & 95,8 & 641,7 \\
\hline Gračišće & 761 & 342 & 44,9 & 370 & 365 & 98,6 & 219,5 \\
\hline Grožnjan & 609 & 310 & 50,9 & 165 & 214 & 129,7 & 254,8 \\
\hline Kanfanar & 732 & 338 & 46,2 & 282 & 410 & 145,4 & 314,9 \\
\hline Karojba & 704 & 283 & 40,2 & 399 & 323 & 81,0 & 201,4 \\
\hline Kaštelir-Labinci & 463 & 272 & 58,7 & 325 & 316 & 97,2 & 165,5 \\
\hline Kršan & 1.578 & 766 & 48,5 & 737 & 776 & 105,3 & 216,9 \\
\hline Labin & 3.681 & 790 & 21,5 & 2.375 & 2.853 & 120,1 & 559,7 \\
\hline Lanišće & 514 & 355 & 69,1 & 74 & 173 & 233,8 & 338,5 \\
\hline Ližnjan & 716 & 441 & 61,6 & 651 & 662 & 101,7 & 165,1 \\
\hline Lupoglav & 584 & 324 & 55,5 & 202 & 271 & 134,2 & 241,8 \\
\hline Marčana & 1.679 & 751 & 44,7 & 752 & 1.071 & 142,4 & 318,4 \\
\hline Medulin & 450 & 419 & 93,1 & 1.002 & 1.006 & 100,4 & 107,8 \\
\hline Motovun & 731 & 228 & 31,2 & 215 & 270 & 125,6 & 402,6 \\
\hline Novigrad & 797 & 186 & 23,3 & 928 & 802 & 86,4 & 370,3 \\
\hline Oprtalj & 708 & 385 & 54,4 & 222 & 258 & 116,2 & 213,7 \\
\hline Pazin & 3.028 & 967 & 31,9 & 2.290 & 1.797 & 78,5 & 245,7 \\
\hline Pićan & 1.141 & 388 & 34,0 & 442 & 495 & 112,0 & 329,3 \\
\hline Poreč & 2.736 & 1.075 & 39,3 & 4.168 & 2.953 & 70,8 & 180,3 \\
\hline Pula & 12.548 & 2.923 & 23,3 & 12.305 & 13.438 & 109,2 & 468,8 \\
\hline Raša & 2.222 & 616 & 27,7 & 734 & 903 & 123,0 & 443,8 \\
\hline Rovinj & 2.617 & 964 & 36,8 & 3.098 & 2.800 & 90,4 & 245,4 \\
\hline Sv. Nedelja & 1.346 & 609 & 45,2 & 538 & 816 & 151,7 & 335,2 \\
\hline Sv. Lovreč & 657 & 283 & 43,1 & 318 & 345 & 108,5 & 251,9 \\
\hline Sv. Petar u Šumi & 414 & 136 & 32,9 & 291 & 209 & 71,8 & 218,6 \\
\hline Svetvinčenat & 1.218 & 405 & 33,3 & 479 & 609 & 127,1 & 382,4 \\
\hline Tinjan & 880 & 425 & 48,3 & 436 & 463 & 106,2 & 219,9 \\
\hline Umag & 2.622 & 785 & 29,9 & 2.875 & 2.319 & 80,7 & 269,4 \\
\hline Višnjan & 1.068 & 453 & 42,4 & 489 & 559 & 114,3 & 269,5 \\
\hline Vižinada & 639 & 257 & 40,2 & 255 & 258 & 101,2 & 251,6 \\
\hline Vodnjan & 2.244 & 723 & 32,2 & 1.363 & 1.058 & 77,6 & 240,9 \\
\hline Vrsar & 458 & 168 & 36,7 & 660 & 444 & 67,3 & 183,4 \\
\hline Žminj & 1.457 & 621 & 42,6 & 812 & 880 & 108,4 & 254,3 \\
\hline ISTRA & 60.167 & 21.278 & 35,4 & 44.971 & 44.825 & 99,7 & 281,8 \\
\hline
\end{tabular}

Indeks starosti $\left(\mathrm{X}_{\mathrm{s}}\right)=\mathrm{P}_{60+} / \mathrm{P}_{0-19} \times 100$.

Napomena: Za grad Pulu 2001. ubrojeni podaci i za naselja Pješčana Uvala, Valbonaša, Vinkuran i

Vintijan koji su izuzeti iz općine Medulin. Za 1961. procjena za naselja Balići I (općina Žminj) i Balići II (općina Barban).

Izvor: Popis stanovništva 1961, knjiga XI, Pol i starost, SZS, Beograd, 1965;

Popis stanovništva, kućanstava i stanova 31. ožujka 2001., CD-ROM, DZS, Zagreb, 2002. 
najveću promjenu indeksa starosti zabilježili su općine/gradovi Fažana (indeks promjene 641,7), Labin (559,7), Pula (468,8), Barban $(462,2)$, Raša $(443,8)$ i Motovun $(402,6)$ (tab. 7). Kod udjela mladih 2001. polove predstavljaju općina Sveti Petar u Šumi $(28,8 \%)$ i Sveta Nedelja (18,5\%), dok je kod udjela starih najveći udio u ukupnom stanovništvu prisutan u općini Lanišće (43,5\%), a najmanji u općini Vrsar (16,4\%).

Sastav stanovništva Istre prema spolu pokazuje porast udjela ženskog stanovništva u ukupnom. Godine 1961. koeficijent feminiteta (broj žena na 100 ili 1000 muškaraca) iznosio je 1022, a 2001. 1064 (tab. 8). Prema rezultatima prvog razmatranog popisa iz 1961. koeficijent feminiteta po općinama i gradovima kretao se od 88 (Vižinada) do 119 (Sv. Petar u Šumi) (tab. 8). Čak 25 općina/gradova imalo je veći udio ženskog, nego muškog stanovništva, da bi se taj broj 2001. povećao na 33. Prema podacima posljednjeg popisa stanovništva polovi vrijednosti kretali su se od 97 (općina Sv. Lovreč) do 116 (općina Grožnjan). Specifični koeficijent feminiteta prema dobi pokazuje manjak ženske populacije u mlađim dobnim skupinama (općenito se rađa više muške djece) na razini Istarske županije (tab. 9). Prevlast muške populacije 1971. pojavljivala se u dobnim skupinama sve do razreda 40-44 godina starosti. Podaci zadnjeg popisa otkrivaju da se ta dominacija "spustila" do razreda 25-29. Neravnoteža prema spolu povećava se u starijim dobnim skupinama (žene u prosjeku žive duže od muškaraca).

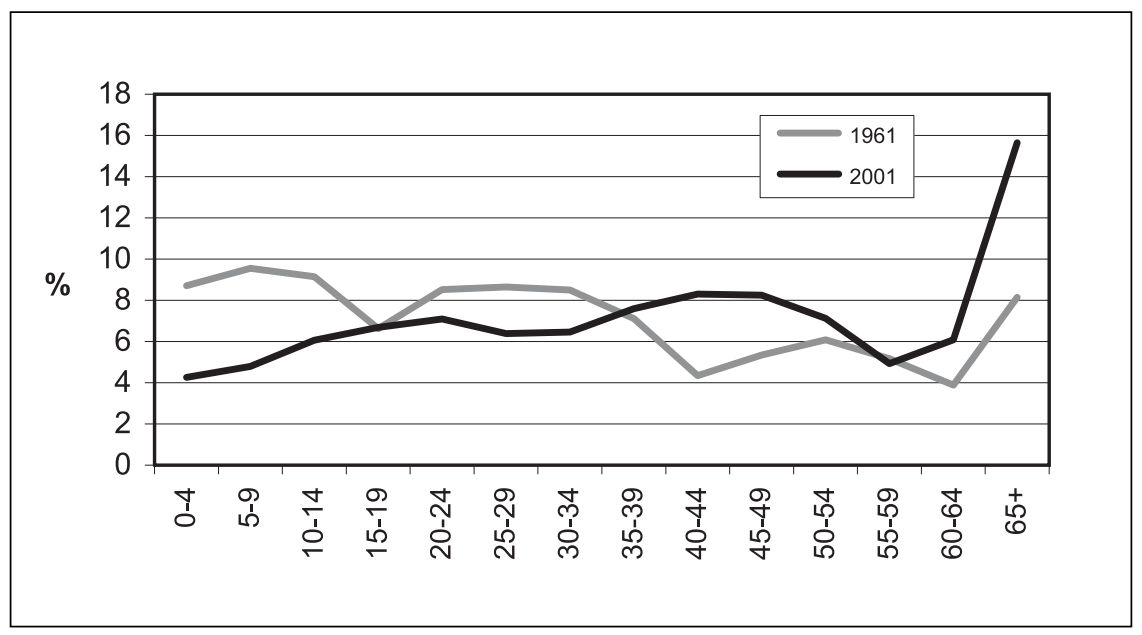

S1. 5. Stanovništvo Istre po dobnim skupinama 1961. i 2001.

Fig. 5 Population of Istria by age groups in 1961 and 2001 


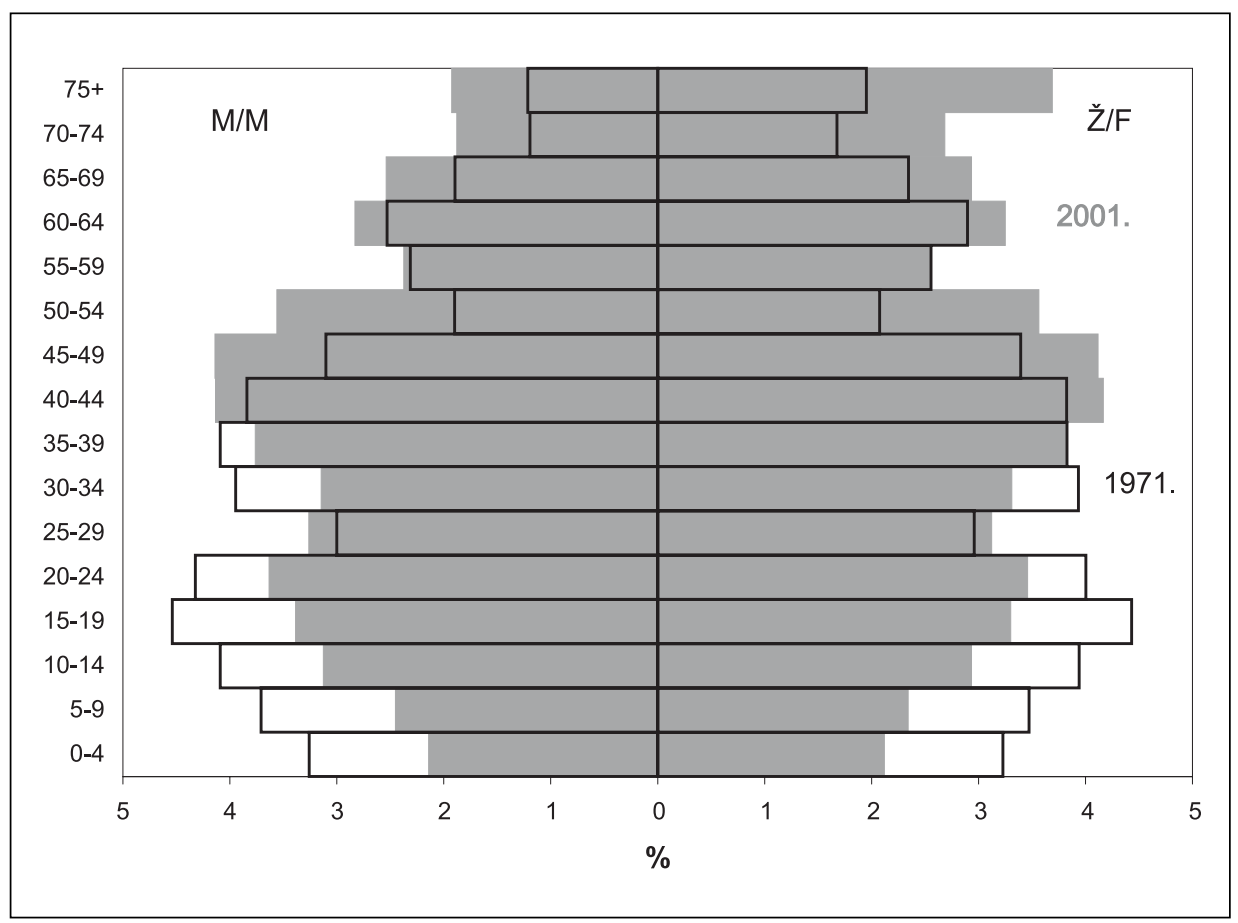

S1. 6. Dobno-spolna struktura stanovništva Istre 1971. i 2001.

Fig. 6 Age-sex structure of population of Istria in 1971 and 2001

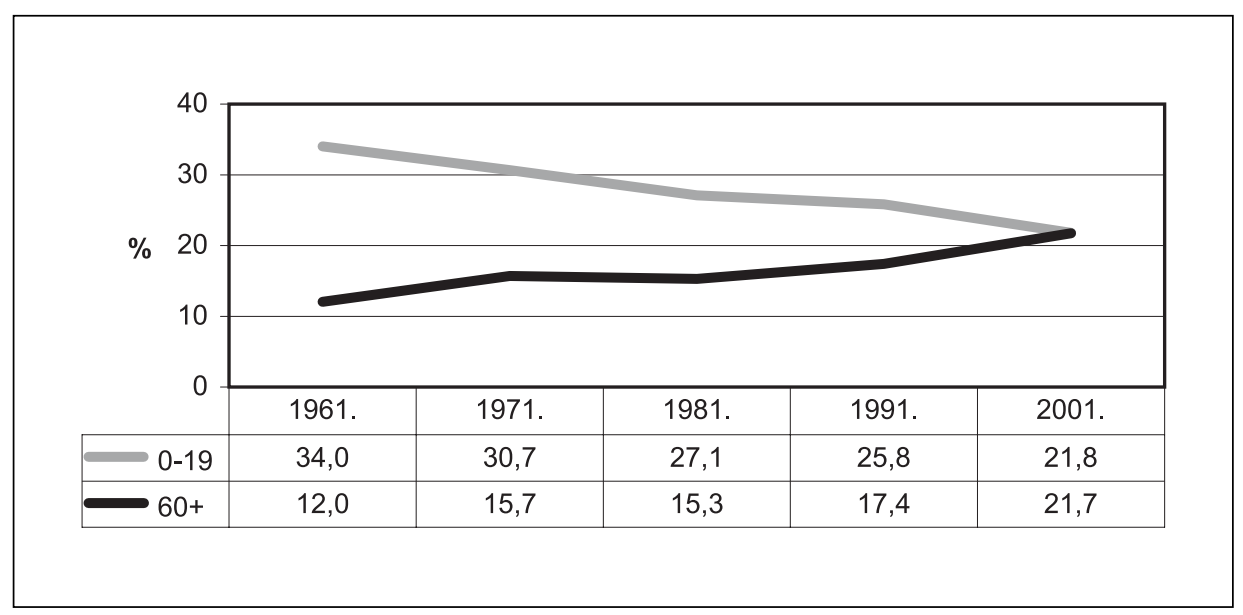

S1. 7. Udio mladog i starog stanovništva Istre u ukupnom 1961. - 2001.

Fig. 7 Shares of young and old population in the total population of Istria 1961-2001 
Tab. 8. Struktura stanovništva Istre prema spolu 1961. i 2001.

Tab. 8 Sex structure of population of Istria in 1961 and 2001.

\begin{tabular}{|c|c|c|c|c|c|c|c|}
\hline \multirow{2}{*}{ Općina/grad } & \multicolumn{3}{|c|}{1961.} & \multicolumn{3}{|c|}{2001.} & \multirow{2}{*}{\begin{tabular}{|c|} 
indeks \\
$2001 . / 1961$. \\
\end{tabular}} \\
\hline & $\mathbf{M}$ & $\check{\mathbf{Z}}$ & $\mathbf{k}_{c}$ & $\mathbf{M}$ & $\check{\mathbf{Z}}$ & $\mathbf{k}_{\mathrm{s}}$ & \\
\hline Bale & 568 & 562 & 99 & 518 & 529 & 102 & 103,2 \\
\hline Barban & 2.033 & 2.074 & 102 & 1.337 & 1.465 & 110 & 107,4 \\
\hline Brtonigla & 969 & 989 & 102 & 778 & 801 & 103 & 100,9 \\
\hline Buje & 2.676 & 2.664 & 100 & 2.567 & 2.773 & 108 & 108,5 \\
\hline Buzet & 3.522 & 3.566 & 101 & 3.032 & 3.027 & 100 & 98,6 \\
\hline Cerovlje & 1477 & 1572 & 106 & 875 & 870 & 99 & 93,4 \\
\hline Fažana & 620 & 651 & 105 & 1.515 & 1.535 & 101 & 96,5 \\
\hline Gračišće & 1063 & 1087 & 102 & 716 & 717 & 100 & 97,9 \\
\hline Grožnjan & 984 & 877 & 89 & 364 & 421 & 116 & 129,8 \\
\hline Kanfanar & 1118 & 1151 & 103 & 710 & 747 & 105 & 102,2 \\
\hline Karojba & 904 & 897 & 99 & 745 & 744 & 100 & 100,6 \\
\hline Kaštelir-Labinci & 788 & 784 & 99 & 659 & 675 & 102 & 103,0 \\
\hline Kršan & 2.412 & 2.376 & 99 & 1.611 & 1.653 & 103 & 104,2 \\
\hline Labin & 5.350 & 4.903 & 92 & 6.115 & 6.311 & 103 & 112,6 \\
\hline Lanišće & 796 & 919 & 115 & 186 & 212 & 114 & 98,7 \\
\hline Ližnjan & 1.271 & 1.365 & 107 & 1.450 & 1.495 & 103 & 96,0 \\
\hline Lupoglav & 908 & 874 & 96 & 463 & 466 & 101 & 104,6 \\
\hline Marčana & 2.519 & 2.534 & 101 & 1.908 & 1.995 & 105 & 103,9 \\
\hline Medulin & 874 & 948 & 108 & 2.936 & 3.068 & 104 & 96,3 \\
\hline Motovun & 902 & 948 & 105 & 468 & 515 & 110 & 104,7 \\
\hline Novigrad & 1.027 & 1.067 & 104 & 1.889 & 2.113 & 112 & 107,7 \\
\hline Oprtalj & 1125 & 1095 & 97 & 473 & 508 & 107 & 110,3 \\
\hline Pazin & 4.071 & 4.318 & 106 & 4.539 & 4.688 & 103 & 97,4 \\
\hline Pićan & 1463 & 1.536 & 105 & 973 & 1.024 & 105 & 100,2 \\
\hline Poreč & 4.061 & 4.155 & 102 & 8.430 & 9.030 & 107 & 104,7 \\
\hline Pula & 18.459 & 18.944 & 103 & 28.033 & 30.561 & 109 & 106,2 \\
\hline Raša & 3.231 & 3.142 & 97 & 1.657 & 1.878 & 113 & 116,5 \\
\hline Rovinj & 3.662 & 4.156 & 113 & 6.820 & 7.414 & 109 & 95,8 \\
\hline Sv. Nedelja & 1.986 & 2.127 & 107 & 1.419 & 1.490 & 105 & 98,0 \\
\hline Sv. Lovreč & 994 & 965 & 97 & 716 & 692 & 97 & 99,6 \\
\hline Sv. Petar u Šumi & 512 & 611 & 119 & 479 & 532 & 111 & 93,1 \\
\hline Svetvinčenat & 1.693 & 1.863 & 110 & 1.077 & 1.141 & 106 & 96,3 \\
\hline Tinjan & 1302 & 1289 & 99 & 888 & 882 & 99 & 100,3 \\
\hline Umag & 3.757 & 3.801 & 101 & 6.234 & 6.667 & 107 & 105,7 \\
\hline Višnjan & 1.602 & 1.584 & 99 & 1.079 & 1.108 & 103 & 103,9 \\
\hline Vižinada & 934 & 826 & 88 & 571 & 566 & 99 & 112,1 \\
\hline Vodnjan & 3.062 & 3.235 & 106 & 2.734 & 2.917 & 107 & 101,0 \\
\hline Vrsar & 633 & 677 & 107 & 1.332 & 1.371 & 103 & 96,2 \\
\hline Žminj & 2.116 & 2.262 & 107 & 1.673 & 1.774 & 106 & 99,2 \\
\hline ISTRA & 87.444 & 89.394 & 102 & 99.969 & 106.375 & 106 & 104,1 \\
\hline
\end{tabular}

Koeficijent feminiteta $\left(\mathrm{k}_{\mathrm{f}}\right)=\check{\mathrm{Z}} / \mathrm{M} \times 100$.

Napomena: Za grad Pulu 2001. ubrojeni podaci i za naselja Pješčana Uvala, Valbonaša, Vinkuran i

Vintijan koji su izuzeti iz općine Medulin.

Za 1961. procjena za naselja Balići I (općina Žminj) i Balići II (općina Barban).

Izvor: Popis stanovništva 1961, knjiga XI, Pol i starost, SZS, Beograd, 1965;

Popis stanovništva, kućanstava i stanova 31. ožujka 2001., CD-ROM, DZS, Zagreb, 2002. 
Tab. 9. Koeficijent feminiteta stanovništva Istre prema dobnim grupama 1971. i 2001.

Tab. 9 Sex ratio of population of Istria by age groups in 1971 and 2001

\begin{tabular}{|c|c|c|c|c|c|c|}
\hline \multirow{2}{*}{ Dobne grupe } & \multicolumn{3}{|c|}{1971.} & \multicolumn{3}{|c|}{2001.} \\
\hline & M & Ž & $\mathbf{k}_{f}$ & M & $\check{\mathbf{Z}}$ & $\mathbf{k}_{f}$ \\
\hline $0-4$ & 5.709 & 5.656 & 991 & 4.419 & 4.368 & 988 \\
\hline $5-9$ & 6.497 & 6.083 & 936 & 5.059 & 4.829 & 955 \\
\hline $10-14$ & 7.166 & 6.905 & 964 & 6.450 & 6.052 & 938 \\
\hline $15-19$ & 7.952 & 7.764 & 976 & 6.986 & 6.808 & 975 \\
\hline $20-24$ & 7.572 & 7.015 & 926 & 7.498 & 7.132 & 951 \\
\hline $25-29$ & 5.257 & 5.184 & 986 & 6.729 & 6.439 & 957 \\
\hline $30-34$ & 6.912 & 6.893 & 997 & 6.494 & 6.829 & 1.052 \\
\hline $35-39$ & 7.166 & 6.706 & 936 & 7.762 & 7.898 & 1.018 \\
\hline $40-44$ & 6.730 & 6.699 & 995 & 8.532 & 8.595 & 1.007 \\
\hline $45-49$ & 5.435 & 5.947 & 1.094 & 8.542 & 8.491 & 994 \\
\hline $50-54$ & 3.325 & 3.636 & 1.094 & 7.348 & 7.352 & 1.001 \\
\hline $55-59$ & 4.052 & 4.478 & 1.105 & 4.900 & 5.269 & 1.075 \\
\hline $60-64$ & 4.433 & 5.074 & 1.145 & 5.841 & 6.701 & 1.147 \\
\hline $65-69$ & 3.321 & 4.108 & 1.237 & 5.237 & 6.051 & 1.155 \\
\hline $70-74$ & 2.092 & 2.936 & 1.403 & 3.877 & 5.535 & 1.428 \\
\hline $75+$ & 2.129 & 3.418 & 1.605 & 3.974 & 7.609 & 1.915 \\
\hline Ukupno & 86.231 & 88.968 & 1.032 & 99.969 & 106.375 & 1.064 \\
\hline
\end{tabular}

Koeficijent feminiteta $(\mathrm{kf})=\check{\mathrm{Z}} / \mathrm{M} \times 1000$.

Izvor: Popis stanovništva i stanova 1971, Pol i starost-I deo: rezultati po naseljima i opštinama, knjiga VIII, SZS, Beograd, 1973; Popis stanovništva, kućanstava i stanova 31. ožujka 2001., CD-ROM, DZS, Zagreb, 2002.

\section{DEMOGRAFSKI UGROŽENA NASELJA}

Popis iz 2001. zabilježio je 648 naselja u Istri. Od tih 648 naselja u njih 637 obitavali su žitelji Istre. Što je s ostalih 11 ? U Kanegri ne živi nitko jer je to turističko naselje; teritorij naselja Sv. Marija na Krasu podijeljen je tako da sada postoje dva istoimena naselja u gradu Umagu i Bujama, s tim da je području grada Buja pripao nenaseljeni dio (da bi se ostvarila izravna veza s naseljem Kanegra). Preostalih devet naselja je bez stanovnika. Postala su "mrtva sela" (sl. 8). To su naselja: Benčići (grad Buzet), Rupeni (grad Poreč), Vrnjak (općina Grožnjan), Frnjolići (općina Sv. Lovreč), Bujarići (općina Višnjan), Mastelići, Piškovica, Trombal i Vranići kod Vižinade (sva u općini Vižinada). Prvo naselje koje je statistika zabilježila (popisom iz 1953.) kao naselje bez stanovnika jest Bujarići. Popis iz 1971. evidentirao je da su i Mastelići, Piškovica i Trombal ostali bez stanovnika. Dvadeset godina kasnije, popisom iz 1991. pridružili su im se Frnjolići i Vranići kod Vižinade. Posljednji popis izdvojio je spomenute Benčiće, Vrnjak i Rupene, ali i dva naselja koja su “oživjela" na papiru. To su naselja Kotli i Ivići koji su 1991. bili bez ijednog žitelja, a zadnjim popisom utvrđeno je da u njima živi po jedan stanovnik.

S obzirom na zamah depopulacije, bilo je zanimljivo izraditi prognozu demografski ugroženih naselja kojima prijeti izumiranje u doglednoj budućnosti. Budući da su parametri 
samo demografski, svjesni smo nedostatka ovakvog "kabinetskog istraživanja", ali mislimo da je ovo koristan prilog demografskom vrednovanju naselja u Istri. ${ }^{20}$ Kriteriji koje smo odabrali bili su sljedeći:

\section{Veličina naselja 2001. $\leq 50$ stanovnika.}

Veličina naselja odabrana je zbog zakonitosti da što je neko naselje manje, to su veći izgledi da će ono postati još manje. Čini nam se da je granica od 50 stanovnika za populacijske značajke Istre realna te da udovoljava uvjetima izrade "crne" demografske perspektive za pojedina naselja. Ovaj prvi kriterij izdvojio je 227 naselja. U tom broju sadržana su i već spomenuta dva novonastala (Katoro, Monterol) i dva "oživjela" naselja (Kotli i Ivići) koja nisu ušla u daljnju analizu jer se ona u njihovom slučaju nije mogla provesti.

\section{Smanjenje u periodu 1971. $-1981 . \geq 15 \%$.}

Toje natprosječno smanjenje jer je u tom periodu smanjenje ukupnog depopulacijskog skupa naselja (sva naselja koja su imala više stanovnika na početku promatranog razdoblja nego na kraju) iznosilo $14,2 \%$. Ovim kriterijem selektirano je 138 naselja.

3. Smanjenje u periodu 1981. -1991 . $\geq 15 \%$.

U ovom razdoblju smanjenje za ukupni depopulacijski skup naselja iznosilo je $13,4 \%$.

Nakon selekcije ovim kriterijem izdvojeno je 78 naselja.

\section{Smanjenje u periodu 1991. - 2001. $\geq 15 \%$.}

Broj depopulacijskih naselja Istre u ovom periodu je 337. Broj stanovnika u tim naseljima 1991. bio je 120612 , da bi se 2001. smanjio na 110 212. To znači da smanjenje iznosi 8,6\%. Izostavili smo sedam velikih naselja (Pula, Labin, Pazin, Vodnjan, Buje, Buzet i Raša) koja također gube broj stanovnika i sada postotak smanjenja iznosi $12,8 \%$ (sa 33214 na 28 947), što je ipak realniji podatak. Tada smo crtu povukli na 15\%. Ovaj kriterij izdvojio je 45 naselja.

\section{Udio mladih (0-19 g.) $<15 \%$.}

Konačno, nakon uporabe i ovog kriterija, izdvojeno je 26 naselja s najlošijim demografskim trendovima.

Za patuljasta naselja s 10 i manje stanovnika "ublažili" smo jedan kriterij. U ovo dodatno razmatranje ušlo je ukupno 13 naselja. Smanjivanjem jednog od kriterija izdvojeno je još sedam naselja. Dakle, ukupno je u Istri 33 ili 5,2\% (od 637 naseljenih 2001 g.) naselja s najnepovoljnijim demografskim trendom kojima prijeti izumiranje (tab. 10, sl. 8). Nema sumnje da je ovakav trend demografskog razvoja pojedinih naselja rezultat brojnih okolnosti. Jedna od važnijih je i naslijeđena populacijsko-naseljska struktura. Dobar dio njih jednostavno nije dovoljno velik za funkcionalno organiziranje društvenog života koji se u njima gasi, devastira ambijent i gubi identitet. Ostaje još ono malo stanovnika koje s punim pravom možemo nazvati etničkom baštinom. 
Tab. 10. Demografski ugrožena naselja Istre

Tab. 10 Demographically endangered settlements in Istria

\begin{tabular}{|c|c|c|c|c|c|c|c|c|c|c|}
\hline \multirow{2}{*}{ Općina/grad } & \multirow[t]{2}{*}{ Naselje } & \multicolumn{4}{|c|}{ Broj stanovnika } & \multicolumn{3}{|c|}{$\begin{array}{l}\text { Međupopisna } \\
\text { promjena }(\%)\end{array}$} & \multicolumn{2}{|c|}{$\begin{array}{c}\text { Mlado } \\
\text { stanovništvo } \\
(0-19) 2001 .\end{array}$} \\
\hline & & 1971. & 1981. & 1991. & 2001. & $\begin{array}{l}\text { 1971.- } \\
1981 .\end{array}$ & $\begin{array}{l}\text { 1981.- } \\
1991 .\end{array}$ & $\begin{array}{l}\text { 1991.- } \\
\text { 2001. }\end{array}$ & aps. & $\%$ \\
\hline BARBAN & Rojnići & 88 & 74 & 61 & 48 & $-15,9$ & $-17,6$ & $-21,3$ & 5 & 10,4 \\
\hline BUZET & Blatna Vas & 41 & 20 & 12 & 8 & $-51,2$ & $-40,0$ & $-33,3$ & 2 & 25,0 \\
\hline BUZET & Duričići & 33 & 22 & 12 & 4 & $-33,3$ & $-45,5$ & $-66,7$ & - & - \\
\hline BUZET & Podkuk & 22 & 6 & 3 & 1 & $-72,7$ & $-50,0$ & $-66,7$ & - & - \\
\hline BUZET & Salež & 45 & 32 & 20 & 17 & $-28,9$ & $-37,5$ & $-15,0$ & 2 & 11,8 \\
\hline BUZET & Sirotići & 55 & 36 & 25 & 18 & $-34,5$ & $-30,6$ & $-28,0$ & 2 & 11,1 \\
\hline KANFANAR & Dubravci & 23 & 26 & 13 & 10 & 13,0 & $-50,0$ & $-23,1$ & 1 & 10,0 \\
\hline KANFANAR & Korenići & 82 & 68 & 50 & 40 & $-17,1$ & $-26,5$ & $-20,0$ & 4 & 10,0 \\
\hline KRŠAN & Kostrčani & 142 & 71 & 54 & 42 & $-50,0$ & $-23,9$ & $-22,2$ & 6 & 14,3 \\
\hline KRŠAN & Zankovci & 58 & 28 & 21 & 10 & $-51,7$ & $-25,0$ & $-52,4$ & 1 & 10,0 \\
\hline LANIŠĆÉ & Dane & 38 & 29 & 21 & 12 & $-23,7$ & $-27,6$ & $-42,9$ & - & - \\
\hline LANIŠĆE & Jelovice & 56 & 45 & 27 & 19 & $-19,6$ & $-40,0$ & $-29,6$ & 1 & 5,3 \\
\hline LANIŠĆE & Klenovšćak & 23 & 14 & 10 & 6 & $-39,1$ & $-28,6$ & $-40,0$ & - & - \\
\hline LANIŠĆE & Kropinjak & 34 & 22 & 15 & 11 & $-35,3$ & $-31,8$ & $-26,7$ & 1 & 9,1 \\
\hline LANIŠĆE & Račja Vas & 102 & 68 & 55 & 34 & $-33,3$ & $-19,1$ & $-38,2$ & 1 & 2,9 \\
\hline LANIŠĆE & Trstenik & 32 & 27 & 20 & 4 & $-15,6$ & $-25,9$ & $-80,0$ & - & - \\
\hline MARČANA & Mutvoran & 57 & 39 & 32 & 23 & $-31,6$ & $-17,9$ & $-28,1$ & 3 & 13,0 \\
\hline \begin{tabular}{|l|} 
OPRTALJ \\
\end{tabular} & Bencani & 24 & 18 & 9 & 8 & $-25,0$ & $-50,0$ & $-11,1$ & - & - \\
\hline \begin{tabular}{|l|} 
OPRTALJ \\
\end{tabular} & Sv. Lucija & 94 & 77 & 50 & 41 & $-18,1$ & $-35,1$ & $-18,0$ & 6 & 14,6 \\
\hline \begin{tabular}{|l|} 
OPRTALJ \\
\end{tabular} & Žnjidarići & 104 & 75 & 52 & 41 & $-27,9$ & $-30,7$ & $-21,2$ & 6 & 14,6 \\
\hline POREČ & Jurići & 8 & 5 & 6 & 5 & $-37,5$ & 20,0 & $-16,7$ & - & - \\
\hline POREČ & Ružići & 16 & 6 & 3 & 1 & $-62,5$ & $-50,0$ & $-66,7$ & - & - \\
\hline POREČ & Šeraje & 7 & 6 & 4 & 2 & $-14,3$ & $-33,3$ & $-50,0$ & - & - \\
\hline RAŠA & Drenje & 102 & 75 & 57 & 41 & $-26,5$ & $-24,0$ & $-28,1$ & 6 & 14,6 \\
\hline SVETI LOVREČ & Kapovići & 5 & 3 & 2 & 1 & $-40,0$ & $-33,3$ & $-50,0$ & - & - \\
\hline SVETI LOVREČ & Knapići & 11 & 8 & 6 & 4 & $-27,3$ & $-25,0$ & $-33,3$ & - & - \\
\hline SVETI LOVREČ & Kršuli & 12 & 8 & 5 & 3 & $-33,3$ & $-37,5$ & $-40,0$ & - & - \\
\hline SVETI LOVREČ & Pajari & 23 & 16 & 10 & 8 & $-30,4$ & $-37,5$ & $-20,0$ & - & - \\
\hline SVETVINČENAT & Peresiji & 85 & 57 & 43 & 28 & $-32,9$ & $-24,6$ & $-34,9$ & 2 & 7,1 \\
\hline VIŠNJAN & Košutići & 21 & 17 & 9 & 8 & $-19,0$ & $-47,1$ & $-11,1$ & 1 & 12,5 \\
\hline VIŠNJAN & Legovići & 13 & 9 & 13 & 8 & $-30,8$ & 44,4 & $-38,5$ & 1 & 12,5 \\
\hline VIŠNJAN & Žikovići & 18 & 13 & 11 & 8 & $-27,8$ & $-15,4$ & $-27,3$ & 1 & 12,5 \\
\hline VIŽINADA & Čuki & 29 & 18 & 10 & 5 & $-37,9$ & $-44,4$ & $-50,0$ & - & - \\
\hline
\end{tabular}

Izvor: Korenčić M., 1979: Naselja i stanovništvo SR Hrvatske 1857-1971., JAZU, Zagreb;

Popis stanovništva, domaćinstava i stanova 1981., Stanovništvo po naseljima, općinama i zajednicama općina, Dokumentacija 553, RZS SRH, Zagreb, 1984;

Popis stanovništva, domaćinstava, stanova i poljoprivrednih gospodarstava 31.ožujak 1991., Stanovništvo u zemlji i inozemstvu po naseljima, Dokumentacija 911, DZS, Zagreb, 1996.

Popis stanovništva, kućanstava i stanova 31. ožujka 2001., CD-ROM, DZS, Zagreb, 2002. 


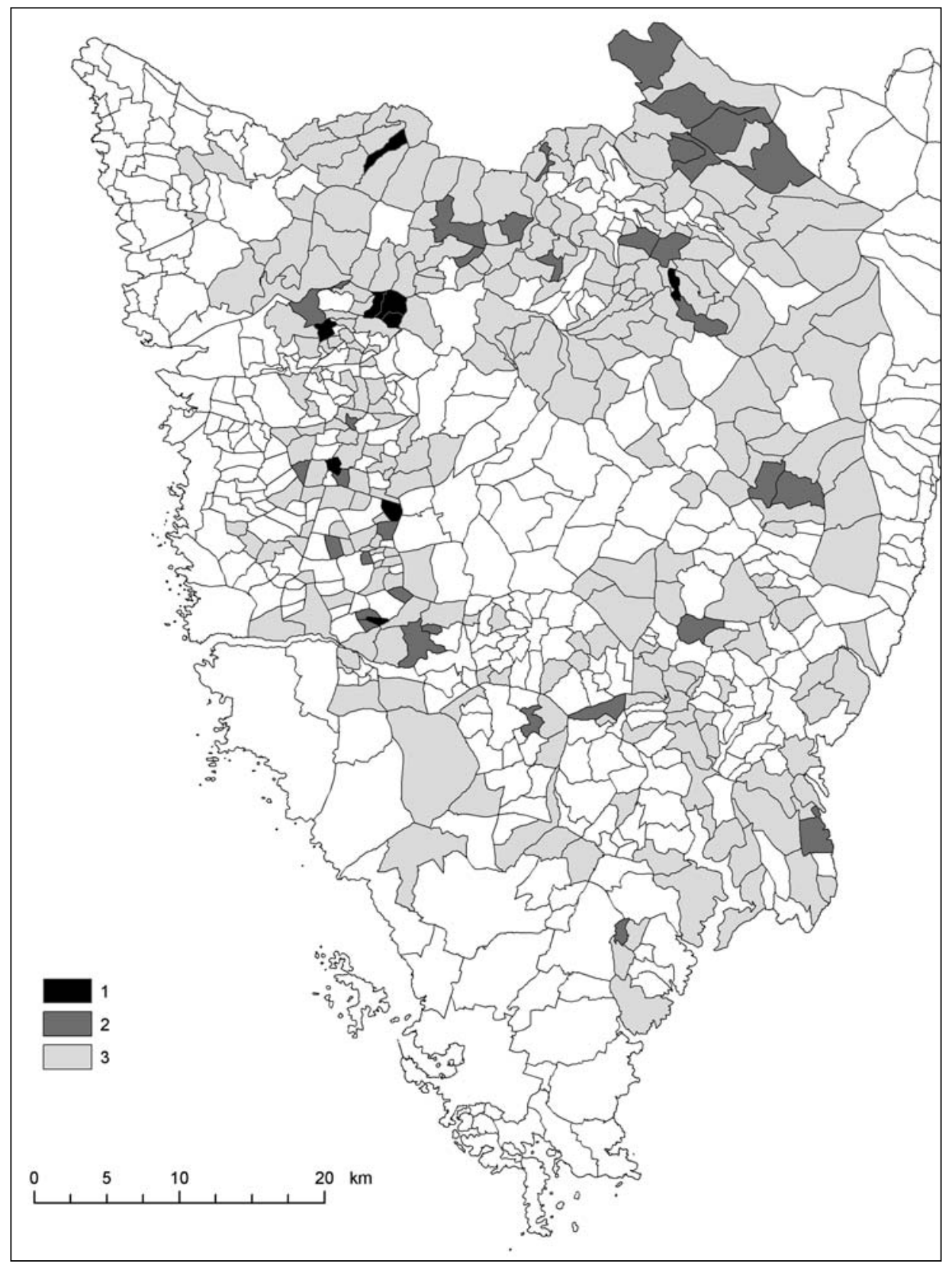

S1. 8. Istra: Izumrla naselja (1), demografski ugrožena (2) i naselja u kojima je broj stanovnika 2001./1948. smanjen $50 \%$ i više (3)

Fig. 8 Istria: Extinct settlements (1), demographically endangered settlements (2) and settlements with population number decreased for 50 per cent and more (2001/1948) (3) 


\section{ZAKLJUČAK}

Nakon snažnog utjecaja emigracije (istarski egzodus) na ukupno kretanje stanovništva Istre do 1971. priobalje se počinje, pod utjecajem razvoja gospodarstva, demografski oživljavati, dok se u unutrašnjosti ruralni egzodus nastavlja na poslijeratnu emigraciju. O dugotrajnosti i intenzitetu procesa depopulacije dovoljno govori podatak da se u čak 15 općina broj stanovnika smanjuje u svim međupopisnim razdobljima. Odgođeni učinci iseljavanja i ratnih gubitaka uzrokovali su (između ostalog) postupno smanjivanje prirodnog prirasta koje je rezultiralo pojavom denataliteta od 1992. na razini Istre, a u periodu od 1991. do 2000. prirodnom depopulacijom u većini $(82,1 \%)$ općina i gradova. U posljednja tri desetljeća (1971. - 2001.) nakon dominantnijeg utjecaja prirodnog prirasta stanovništva na ukupno kretanje u prvom desetljeću (1971. - 1981.), glavni moderator općeg kretanja pučanstva na razini županije postaje pozitivan migracijski saldo koji je u razdoblju 1981. - 1991. pozitivniji od prirodnog prirasta, a u periodu 1991. - 2001. anulira utjecaj prirodnog pada stanovništva. Demografski razvoj nije mogao ostaviti bez posljedica ni dobnu strukturu stanovništva. Udio mladog stanovništva je u stalnom opadanju, a indeks starosti pokazuje da je u 23 općine/gradova veći broj starog nego mladog stanovništva, što ukazuje na slab vitalni potencijal i slabu reproduktivnu moć. U uvjetima dugotrajne prostorne razlike naseljenosti i stihijskog odvijanja preraspodjele stanovništva te razrjeđivanja naseljske strukture, mnoga su naselja prepuštena izumiranju. Prepoznali smo ih, s najbližom perspektivom takve konačnice, 33 ili 5,2\%. Kompleksan društvenogospodarski razvoj prouzročio je koncentraciju stanovništva u gradovima na zapadnoj i južnoj obali. Suvremeni uvjeti načina života (poboljšana infrastruktura, informatizacija, sve bolja prometna povezanost, zdrav život izvan urbanih centara) ne ukazuju na nužnost poklapanja mjesta rada i mjesta stanovanja ("periferija" postaje sve bliža), stoga bi i manja mjesta mogla u bližoj budućnosti postati atraktivnija te demografski oživjeti.

POZIVNE BILJEŠKE

1. Današnji prostor hrvatskog dijela Istre u njezinom je sastavu od 1954. (Memorandum o suglasnosti) uz manju korekciju granice 1956. kada su naselja Abitanti, Belvedur, Brezovica, Gradin, Koromači-Boškini, Močunigi, Pregara i Sirči pripala Sloveniji (Sl. list FNRJ, br. 15/1956).

2. Popis stanovništva, kućanstava i stanova 31. ožujka 2001.: stanovništvo prema spolu i starosti, po naseljima, Statistička izvješća 1167, DZS, Zagreb, 2003., str. 271.

3. Godine 2001. Pješčana Uvala imala je 576, Valbonaša 53, Vinkuran 501 i Vintijan 126 stanovnika.

4. Ukupno u sva četiri naselja od 1997. do 2000. bilo je 20 živorođenih i 33 umrlih.

5. Opširnije o tom popisu i okolnostima njegovog provođenja donosi M. Mirković (1963) u članku "Tri etničke linije”. U navedenom popisu stanovništva naselje Bastići navedeno je dva puta. Pod Završje (str. 23) s 27 stanovnika i pod Oprtalj (str. 54) s istim brojem stanovnika. Isto tako i naselje Gržići s podatkom od 25 stanovnika pod Završje (str. 23) te pod Oprtalj s 24 stanovnika (str. 54). Nadalje, kod ukupnog podatka za Boljun (str. 217 ) pogrešno je zbrojen podatak za ukupno stanovništvo pa umjesto 697 treba stajati 699. Zaseok Valari se spominje dva puta. Prvi put pod Sovišćine (str. 49) sa 38 stanovnika i drugi put pod Senj (str. 497) s isto 38 stanovnika. Korekcijom ovih propusta, 1945. je na današnjem teritoriju Istarske županije živjelo 210776 stanovnika (uzmemo li da su Gržići imali 25 stanovnika). 
6. Prirodno kretanje stanovništva u 1998., Statistička izvješća 1081, DZS, Zagreb, 2000, str. 7.

7. O tome Božo Milanović piše: "Gradnja privatnih porušenih kuća vršila se veoma sporo i malo gdje i to obično bez državne pomoći. Usprkos premnogim obećanjima, danim u vrijeme narodnooslobodilačke borbe, nije se država nikada obavezala, da će plaćati ratnu odštetu i podizati pojedincima u ratu porušene domove. Samo u nekoliko sela se država pobrinula za to.” (Milanović 1996, 152).

8. Nedostatak uspoređivanja ovih podataka predstavlja činjenica da postoji razlika u definiciji poljoprivrednog i ukupnog stanovništva u popisima 1961. i 2001.

9. Gradnja tunela Učka započeta je 1948. te je iste godine obustavljena. Tunel je otvoren tek krajem 1981.

10. U Istri postoji (odnosno, nekad je postojalo jer su neka izumrla) više od 2442 naselja i dijelova naselja tj. zaselaka (izbrojano prema Korenčić 1979).

11. Prema naseljskoj strukturi u vrijeme popisa iz 1948. to su bila naselja: Pula 21 065, Rovinj 7 863, Labin 3798 (4 011 prema današnjem opsegu s naseljem Kature), Vodnjan 3 482, Raša 2 714, Poreč 2558 (3 156 prema današnjem opsegu s još šest naselja: Gulići, Mali Maj, Materada Maj, Špadići, Veli Maj, Vranići kod Poreča), Pazin 2416 (2 526 prema današnjem opsegu s naseljima Foškići i Stari Pazin), Buje 2 293, Umag 1909 (s naseljem Umag-Komunela), Vrsar 1 566, Brtonigla 1 537, Bale 1 496, Novigrad 1 476, Galižana 1 303, Marčana 1 255, Sveti Petar u Šumi 1 165, Tar 1 159, Motovun 1032.

12. To su naselja: Pula 58594 (prema novom ustroju), Rovinj 13 467, Poreč 10 448, Labin 7 904, Umag 7769 , Pazin 4 986, Vodnjan 3 406, Fažana 3 050, Buje 3 001, Novigrad 2 629, Medulin 2 580, Vrsar 1 872, Buzet 1 721, Raša 1 653, Rabac 1 472, Galižana 1 349, Vinež 1 163, Marčana 1015 i Sveti Petar u Šumi 1011.

13. Talijanska historiografija koristi nazive egzodus, izgnanici (tal. esule) i izbjeglice (tal. profughi). Iako način odlaska većine tih ljudi jest bijeg, s pravnog vidika postoji određena razlika. Na temelju izjave o opciji zadržali su svoje talijansko državljanstvo i sva prava, uključujući i odštetu za nekretnine (Zagradnik 1998).

14. Opcija-sloboda biranja; pravo stanovnika područja koje je od jedne države pripalo drugoj da mogu birati između dva državljanstva, uz određene uvjete (Ibler 1987).

15. A. Miculian navodi da prva faza traje od rujna (ili prije) 1943. do svršetka rata, a druga neposredno nakon rata do Mirovnog ugovora. Širi razmjeri počinju nakon potpisivanja ugovora (Miculian 1991).

16. S obzirom na demografsku masu, broj od 20000 iseljenih iz dijela Bujštine pod Zonom B čini nam se prevelik. G. Trani navodi da je iz tog dijela od 8. listopada 1953. do kraja kolovoza 1956. iselilo 7831 osoba (Trani 1980).

17. Popis stanovništva 1961, knjiga XII, Migraciona obeležja, SZS, Beograd, 1966., Popis stanovništva, kućanstava i stanova 31. ožujka 2001.: http://www.dzs.hr/Hrv/Popis\%202001/popis20001.htm.

18. Tako Blažević navodi: "Polarizaciju naselja i širenje urbane mreže pothranjuju migracijska strujanja unutar regije, ali i spontana doseljavanja iz drugih geografskih cjelina. Motivi napuštanja "starih ognjišta" poglavito se svode na školovanje i traženje zaposlenja. Osobito izdašna vrela unutrašnjih i vanjskih migracija nalaze se na području: gornja Bujština-Ćićarija-zapadni obronci Učke-Žminjština. Tradicionalni migracijski tokovi otamo se zrakasto razilaze prema sjeverozapadu (Umag, Poreč), jugozapadu i jugu (Rovinj, Pula) te jugoistoku (Labin, Rijeka)" (Blažević 1994, 544). Kao prilog tvrdnji navodimo rezultat jednog istraživanja (ankete) prema kojem je iz bivše općine Buzet od 1961. do 1970. iselilo 540 stanovnika (ili 28,1\% svih iseljenih) u priobalje dok je samo 5,8\% emigranata otišlo u druga naselja unutrašnje Istre (Baučić 1970). Udio emigranata iz Pazinštine koji su iselili u obalna naselja (uglavnom u Pulu) u poslijeratnom razdoblju iznosi čak 58\%, a onih koji su iselili u druga naselja u unutrašnjosti gotovo je jednak onom iz Buzeštine, svega 6\% (Nejašmić 1980).

19. Indeks starosti izračunava se po formuli: $\mathrm{Xs}=\mathrm{P}_{60+} / \mathrm{P}_{0-19} \times 100$.

20. Prema sličnom istraživanju koje je izradio Nejašmić za cijelu Hrvatsku u Istri bi (otprilike do 2020.) izumrlo 178 naselja (Nejašmić 1991). Zbog rezultata koje donose dva popisa nakon te prognoze (1991. i 2001.) činilo nam se da su mnoga naselja ipak otpornija pa smo izradili novu prognozu, a i nakon svakog popisa stanovništva potrebno je takve analize revidirati. 
Ivan Zupanc - Demogeografski razvoj Istre od 1945. do 2001.

\section{LITERATURA}

Aćimović M., 1993: Neka gospodarska i demografska kretanja u Istri, Gospodarstvo Istre 6 (2), 141-153

Baldaš V., 2003: Beram-demografska obilježja, u Labinjan G. (ur.) Beram u prošlosti, Katedra Čakavskog sabora za povijest Istre, Pazin, 311-332

Bartolić A., 1983: Kretanje i struktura stanovništva, u Ivetac J. (ur.) Karojba i okolica: Zbornik 1, Mjesna zajednica Karojba, Karojba, 17-26

Bartolić A., 1999: Stanovništvo općine Cerovlje, u Šiklić J. (ur.) Cerovljanski zbornik: zbornik radova sa znanstvenog skupa: Cerovlje i okolica od prapovijesti do danas u povodu obilježavanja 500. obljetnice spomena imena Cerovlja, Skupština udruga Matice hrvatske Istarske Županije; Poglavarstvo općine Cerovlje, Pazin, 161-169

Bartolić A., 2002: Stanovništvo općine Gračišće, u Šiklić J. (ur.) Gračaški zbornik: zbornik radova sa znanstvenog skupa: Gračišće i okolica od prapovijesti do danas u povodu obilježavanja 800 . obljetnice spomena imena Gračišća, Skupština udruga Matice hrvatske Istarske županije; Poglavarstvo općine Gračišće, Pazin, 123-134

Bartolić A. i Perentin N., 1989: Demografska kretanja u općini Pazin, Pazinski memorijal 19 (2), 59-70

Bašić K., 1990: Istra-pregled stanovništva i naseljenosti, Geografski horizont 37 (2), 27-32

Baučić I., 1970: Suvremena demografska kretanja u Buzeštini i njihove gospodarske posljedice, Istarski mozaik 5, 51-67

Bertić I., 1997: Istra-geografska obilježja, Geografski horizont 43 (2), 11-34

Blažević I., 1967: Motovun: prilog poznavanju mlađe migracije stanovništva, Istarski mozaik 6, 371-376

Blažević I., 1991: Demografske značajke Istre, Gospodarstvo Istre 4, 7-15

Blažević I., 1994: Demografski aspekt urbanih središta Istarske županije, Susreti na dragom kamenu 19, 541552

Brazda M., 1971: Broj i razmještaj stanovništva Istre u poslijeratnom razdoblju: prilog poznavanju demografskih obilježja Istre, Geografski horizont 17 (3-4), 29-36

Dukovski D., 2001: Egzodus talijanskog stanovništva iz Istre, Časopis za suvremenu povijest 33 (3), 633-667

Friganović M., 1990: Demogeografija: stanovništvo svijeta, Školska knjiga, Zagreb

Gelo J., 1987: Demografske promjene u Hrvatskoj od 1780. do 1981. godine, Globus, Zagreb

Grgurević, O., 2001: Prostorno-demografska valorizacija naselja Istarske županije, Prostor 22 (2), 93-98.

Ibler V., 1987: Rječnik međunarodnog javnog prava, Informator, Zagreb

Kopal M., Ancelj F.-B., Kopal F. 1995: Gospodarska, demografska i ostala obilježja općine Svetvinčenat, Gospodarstvo Istre 8 (1-2), 3-11

Korenčić M., 1979: Naselja i stanovništvo SR Hrvatske 1857-1971., JAZU, Zagreb

Kušen E., 1987: Pozitivni i negativni utjecaj turizma na demografska kretanja na Poreštini, Susreti na dragom kamenu 15, 337-346

Laušić A., 1987: Uzroci i oblici iseljavanja iz Istre nakon drugog svjetskog rata, Zapošljavanje i udruženi rad 12 (3), 369-387

Medica K., 1995: Sodobno organizacijsko povezovanje Slovencev v Hrvaški Istri: prispevek k raziskovanju, u Kržišnik-Bukić V. (ur.) Slovenci v Hrvaški, Inštitut za narodnostna vprašanja, Ljubljana, 391-400

Memorandum o saglasnosti između vlade Italije, Ujedinjene Kraljevine, Sjedinjenih Država i Jugoslavije o Slobodnoj Teritoriji Trsta, Službeni list FNRJ-MUIDS, br. 6/1954 
Miculian A., 1991: Historiografija i publicistika o egzodusu: kritička opažanja, Pazinski memorijal 22, 109 119

Milanović B., 1996: Istra u 20. stoljeću: rat i oslobođenje, "Josip Turčinović”, Pazin

Minčir Đ., 1985: Demografska kretanja u općini Labin, Susreti na dragom kamenu 13, 195-218

Minčir Đ., 1986: Demografska kretanja u općini Pazin u poslijeratnom razdoblju (s osvrtom na utjecaj razvoja industrije), Susreti na dragom kamenu 14, 481-501

Minčir Đ., 1989a: Tendencije kretanja stanovništva Istre (od 1857. do 1981. godine), Gospodarstvo Istre 2 (1), 23-28

Minčir Đ., 1989b: Analiza i prognoza demografskih kretanja u općini Pula, Gospodarstvo Istre 2 (3), 23-40

Minčir Đ., 1991: Demografska kretanja u pojedinim općinama i dijelovima Istre, Gospodarstvo Istre 4 (1), $37-53$

Minčir Đ., 1995: Razvoj stanovništva grada Poreča (1961.-1991.), Gospodarstvo Istre 8 (1-2), 37-52

Mirković M., 1963: Tri etničke linije, Problemi sjevernog Jadrana 1, 1-36

Nejašmić I., 1980: Migracija kao faktor demografskih promjena u Pazinštini: prilog populacijsko-gospodarskoj problematici srednje Istre u razdoblju 1945-1975. godine, Teme o iseljeništvu 9, 1-252

Nejašmić I., 1991: Depopulacija u Hrvatskoj: korijeni, stanje, izgledi, Institut za migracije i narodnosti; Globus, Zagreb

Odluka o odobrenju promjene granica između Narodne Republike Hrvatske i Narodne Republike Slovenije, Službeni list FNRJ, br. 15/1956

Odluka o razdvajanju naselja Banjole, Službene novine Županije Istarske, br. 4/1996

Pavlović M., 1952: Agrarana reforma u Istri od godine 1946.-1948, Rad JAZU 288, 185-204

Pravilnik o opciji osoba sa područja pripojenog Federativnoj Narodnoj Republici Jugoslaviji po Ugovoru o miru sa Italijom, Službeni list FNRJ, br. 109/1947

Radica T., 1980: Prilog demografskoj valorizaciji naselja u prostornom planiranju i uređenju na primjeru Istre, u Sić M. (ur.) Spomen zbornik proslave 30. obljetnice Geografskog društva Hrvatske održane u Zagrebu 6. i 7. prosinca 1977., Geografsko društvo Hrvatske, Zagreb, 161-172

Roglić J., 1946 (ur.) Cadastre national de l'Istrie d'après le Recensement du 1 ${ }^{\text {er }}$ Octobre 1945, L'Institut Adriatique, Sušak

Rojnić M., Percan I. i Verbanac T., 1973: Društveno-ekonomska integracija Istre, u Padjen J. i Žuljić S. (ur.) Istra i njeni razvojni putovi, Ekonomski institut, Zagreb, 140-153

Saopćenje Ministarstva unutrašnjih poslova FNRJ o sporazumu između Federativne Narodne Republike Jugoslavije i Republike Italije o opciji osoba, Službeni list FNRJ, br. 1/1951, 12/1951

Šiklić J., 2003: Stanovništvo općine Lupoglav od 1857. do 2001. godine, u Jakovljević B. (ur.) Zbornik općine Lupoglav, "Josip Turčinović”; Općinsko vijeće Općine Lupoglav, 63-70

Trani G., 1980: Problemi di quantificazione del fenomeno dell'esodo, u Colummi C., Ferrari L., Nassisi G. i Trani G. Storia di un esodo: Istria 1945-1956, Istituto regionale per la storia del movimento di liberazione nel Friuli-Venezia Giulia, Trieste, 565-577

Ukaz o ratifikaciji Ugovora o miru sa Italijom, Službeni list FNRJ, br. 74/1947

Uredba o ratifikaciji sporazuma između Jugoslavije i Italije o regulisanju nerešenih slučajeva opcija za italijansko državljanstvo, Službeni list SFRJ-MUIDS, br. 8/1965

Wertheimer-Baletić A., 1999: Stanovništvo i razvoj, Mate, Zagreb 
Zagradnik M., 1998: Odseljevanje in optiranje za italijansko državljanstvo iz dela Primorske, ki je bil z mirovno pogodbo priključen k LR Sloveniji, Acta Histriae VI, 187-203

Zakon o izmjeni i dopuni zakona o područjima županija, gradova i općina u Republici Hrvatskoj, Narodne novine, br. 129, Zagreb, 2000

Zakon o izmjeni zakona o područjima županija, gradova i općina u Republici Hrvatskoj, Narodne novine, br. 107, Zagreb, 2003

Zakon o jugoslavenskom državljanstvu, Službeni list SFRJ, br. 38/1964

Zakon o područjima županija, gradova i općina u Republici Hrvatskoj, Narodne novine 10/1997

Zakon o ratifikaciji Ugovora između Socijalističke Federativne Republike Jugoslavije i Republike Italije, Službeni list SFRJ-MU, br. 1/1977

Zelenika, J., 1973: Poslijeratna razvojna politika, u Padjen J. i Žuljić S. (ur.) Istra i njeni razvojni putovi, Ekonomski institut, Zagreb, 110-139

Zupanc I., 2001a: Depopulacija sjeverne hrvatske Istre, Dela 16, 179-191

Zupanc I., 2001b: Demografska kretanja sjeverne hrvatske Istre od 1857. do 1991. godine, Annales 11 (2), 321-342

Žerjavić V., 1993: Doseljavanja i iseljavanja s područja Istre, Rijeke i Zadra u razdoblju 1910-1971., Društvena istraživanja 2 (4-5), 631-656

Žmak J., 2003: Stanovništvo Buzeštine od 1880. godine, Buzetski zbornik 29, 157-174

Žuljić S., 1973: Opće značajke urbanog sistema, u Padjen J. i Žuljić S. (ur.) Istra i njeni razvojni putovi, Ekonomski institut, Zagreb, 157-171

\section{SUMMARY}

\section{Population Development of Istria in the Period 1945-2001}

\section{Ivan Zupanc}

The very passing through interior Istria enables us notice uncultivated terraces (fossilised landscape), abandoned houses, even whole villages, or rural entities or half-abandoned towns. There is a completely different picture on the coast and coastal area - an advanced littoralisation process. Questions pose themselves: why is there such a difference on such a small distance; how come that the area of interior Istria is demographically (and not only demographically) so devastated and forgotten? Just that spatial aspect of population study makes research field of population geography.

This work's purpose is to analyse Istria's demographic development after the Second World War (in the period 1945-2001) and so contribute to the common cognition about population characteristics of Istiria. In order to be able to compare the decades-old retrospect of demographic features on municipality and town level, it was necessary to use the data 
on settlement level and reduce them to the existing territorial structure (29 municipalities and 10 towns). A powerful depopulation of the total population number after the end of the Second World War, took place until the 1971 census (with an insignificant increase of 1\% in the period 1953-1961). In that period (until 1971), the population number declined in the majority of municipalities/towns. The municipality of Lanišće on Ćićarija (karst natural base), and so called upper Bujština (today mostly the area of the municipalities of Grožnjan and Oprtalj) were especially marked by depopulation intensity. After a powerful impact of emigration ("Istrian exodus" as a consequence of the Second World War) on the total population change in Istria until 1971, the coastal area started to revive demographically under the influence of economy, while the rural exodus in the interior was a continuation of the post-war emigration. In the following two decades (1971-1981 and 1981-1991), Istria's demographic development was the most propulsive in the whole post-war period. In the inter-census period 1971-1981, 12 municipalities/towns realised the population number increase, and in the period 1981-1991, so did even 17 of them. In the last intercensus period (1991-2001), the number of municipalities and towns, where the population number increased, remained approximately the same (16), but the total number of Istria's population insignificantly increased (for 1\%). In the inter-census period 1971-1981, the total population of Istria increased for 7.5 per cent, and in the following period (1981-1991) for 8.5 per cent. The datum that even in 15 municipalities the population number decreased in all inter-census periods is a sufficient proof of a long duration and intensity of the depopulation process. If we compare the years 1948 and 2001, we discover that the population number increased in 12 municipalities/towns, and declined in the remaining 27 ones. The greatest increase took place in Fažana (index 381.7), while the northern municipalities were remarkable for an extreme depopulation: Lanišće (-87.7\%), Grožnjan (-77.4\%) and Oprtalj (-74.2\%). Population density in Istria grew from 65.2 pers $/ \mathrm{km}^{2}$ (in 1948) to 73.4 pers $/ \mathrm{km}^{2}$ (in 2001). Differentiation according to population density is more prominent, so we have the northern, least populated part of Istria (Lanišce, Lupoglav, Grožnjan), and the extreme southern part of Istria (Pula, Fažana and Medulin). The population density poles are Pula with 1,093 pers $/ \mathrm{km}^{2}$ and the municipality of Lanišće with 2.8 pers $/ \mathrm{km}^{2}$ (the third least populated municipality in Croatia after Civljane and Udbina).

Postponed effects of out-migration and war losses caused (among other things) a gradual decline of natural increase, which resulted in denatality on the level of Istria since 1992, and in natural depopulation in the majority (32 or $82.1 \%$ ) of municipalities and towns in the period 1991-2000. In the last three decades (1971-2001), after a more dominant impact of the population natural increase on the total change in the first decade (1971-1981), the net migration gain, which was more positive than the natural increase in the 1981-1991 and 1991-2001 periods, annulled the influence of the population natural decrease, became the main moderator of the general population change in the County of Istria. During the 1971-1991 period, the general population trend in Istria had the characteristic of expansion by in-migration (type $\mathrm{I}_{4}$ ). On municipality level, in the first decade 1971-1981, type $\mathrm{E}_{4}$ (extinction trend) was the most widespread. It was detected in 18 or 46.2 per cent of municipalities. In the period 1981-1991, the proportion of in-migration and out-migration towns/municipalities changed to the benefit of the first ones: 23:16. But totally, type $\mathrm{E}_{4}$ continued to be the most numerous. It prevailed mostly in the same municipalities as in the previous period. In the last inter-census period (1991-2001) the 
population of Istria grew by in-migration, specifically exclusively under the influence of in-migration (because of natural decrease), so that the general population trend $\mathrm{I}_{3}$ - was a poor regeneration by in-migration. Number of municipalities and towns with the in-migration type of general population trend grew to 31 , out of which type $\mathrm{I}_{4}$ prevailed in 15 - a very poor regeneration by in-migration.

Consequently, during the 1971-1981 period, depopulation of municipalities was primarily caused by out-migration. In the period 1981-1991, the situation changed essentially. Negative natural population increase became the principal depopulation factor on municipality level (more deaths than births). Depopulation under a dominant influence of natural decrease continued in the last inter-census period 1991-2001 as well. Out of 23 depopulating municipalities/towns, 15 lost population exclusively because of more deaths than births, five municipalities depopulated by the interaction of negative natural increase and out-migration, but under a more powerful impact of natural decrease.

Demographic development caused an accelerated ageing process of population. In 1961, the ageing index (proportion between old: 60+ and young population: 0-19) in Istria figured out at 35.4, and according to the last census results 99.7. The young population share permanently declined (in 1961, 34\%, in 2001, 21.8\%) with a simultaneous growth of the old, who in 2001, with 21.7 per cent, almost reached the young. The ageing index shows that in 2001, there was a larger number of old than young population in 23 municipalities and towns, which points to a poor vital potential and reproductive power. In 1961 already, 22 or 56.4 per cent of administrative-territorial units passed the critical value (40\%), and ranged from 14.9 (municipality of Fažana) to 93.1 (municipality of Medulin). The census of 2001 discovered that all municipalities/towns had passed the critical value of 40 per cent, and that there were even 23 more old than young ones (index over 100). The following municipalities/towns had the smallest ageing index: Vrsar (67.3), Poreč (70.8) and Sv. Petar u Šumi (71.8), and the following ones had the greatest ageing index: Lanišce (233.8), Sv. Nedelja (151.7), Kanfanar (145.4), Barban (145.3) and Marčana (142.4). As to the share of the young, the poles were represented by the municipalities of Sveti Petar u Šumi $(28.8 \%)$ and Sveta Nedelja (18.5\%), while the largest share of the old in the total population could be found in the municipality of Lanišce $(43.5 \%)$, and the smallest one in the municipality of $\operatorname{Vrsar}(16.4 \%)$.

Under the conditions of long spatial population differences, spontaneous redistribution of population and settlement structure dilution, many settlements have been left to extinction. By means of the chosen demographic criteria (settlement size, population number decline in the period 1971-2001, and share of the young), we have "discovered" demographically the most endangered settlements in Istria. There are 33 or 5.2 per cent of such settlements in Istria. Such trend of demographic development in particular settlements is the result of numerous circumstances. One of the most important ones is the inherited population-settlement structure. A big number of these settlements are simply not large enough for a functional organisation of social life, which fades away there, devastates the ambience and loses identity. There are still few inhabitants that can be called ethnic heritage. A complex socio-economic development has caused concentration of population in coastal (western and southern coasts) towns. Modern life conditions (improved infrastructure, informatisation, better traffic connections, and healthy life out of urban centres) do 
not necessarily require that people live in the place of work ("periphery" becomes closer and closer), therefore, smaller places could become more attractive and demographically revive in near future.

Primljeno (Received): 4 - 5 - 2004

Prihvaćeno (Accepted): 14 - 6 - 2004

Ivan Zupanc, asistent,

Geografski odsjek, Prirodoslovno-matematički fakultet, Marulićev trg 19,

10000 Zagreb, Hrvatska/Croatia,

e-mail: izupanc@geog.pmf.hr 